\title{
An h-Type Thioredoxin Functions in Tobacco Defense Responses to Two Species of Viruses and an Abiotic Oxidative Stress
}

\author{
Lijun Sun, ${ }^{1,2}$ Haiying Ren, ${ }^{1,3}$ Ruoxue Liu, ${ }^{1}$ Baoyan Li, ${ }^{1}$ Tingquan Wu, ${ }^{1}$ Feng Sun, ${ }^{1}$ Huimin Liu, ${ }^{1}$ \\ Xiaomeng Wang, ${ }^{1}$ and Hansong Dong ${ }^{1}$ \\ ${ }^{1}$ Ministry of Agriculture of R. P. China Key Laboratory of Monitoring and Management of Crop Pathogens and Insect Pests, \\ Nanjing Agricultural University, Nanjing, 210095, China; ${ }^{2}$ Nanjing Institute for Comprehensive Utilization of Wild Plants, \\ Nanjing, 210042, China; and ${ }^{3}$ Institute of Plant Protection and Microbiology, Zhejiang Academy of Agricultural Sciences, \\ Hangzhou, 310021, China
}

Submitted 31 January 2010. Accepted 7 July 2010.

Various thioredoxin (Trx) proteins have been identified in plants. However, many of the physiological roles played by these proteins remain to be elucidated. We cloned a $T R X h$ like gene predicted to encode an h-type Trx in tobacco (Nicotiana tabacum) and designated it NtTRXh3, based on the biochemical activity of the NtTRXh3 protein. Overexpression of $N t T R X h 3$ conferred resistance to Tobacco mosaic virus and Cucumber mosaic virus, both of which showed reduced multiplication and pathogenicity in NtTRXh3overexpressing plants compared with controls. NtTRXh3 overexpression also enhanced tobacco resistance to oxidative stress induced by paraquat, an herbicide that inhibits the production of reducing equivalents by chloroplasts. The NtTRXh3 protein localized exclusively to chloroplasts in coordination with the maintenance of cellular reducing conditions, which accompanied an elevation in the glutathione/glutathione disulfide couple ratio. NtTRXh3 gene expression and NtTRXh3 protein production were necessary for these defensive responses, because they were all arrested when $N t T R X h 3$ was silenced and the production of NtTRXh3 protein was abrogated. These results suggest that NtTRXh3 is involved in the resistance of tobacco to virus infection and abiotic oxidative stress.

Thioredoxin (Trx) is a general designation for small, multifunctional redox proteins found in all living organisms (Meyer et al. 2005, 2009; Park et al. 2009; Rivas et al. 2004). Trx proteins depend on the conserved $\mathrm{WC}(\mathrm{G} / \mathrm{P}) \mathrm{PC}$ motif to catalyze thiol-disulfide interchanges (Baumann and Juttner 2002; Schurmann and Jacquot 2000; Tarrago et al. 2010). Due to their intrinsic biochemical activity, Trx proteins can regulate various redox pathways and play a significant role in the maintenance of cellular redox homeostasis (Gelhaye et al. 2004b; Hisabori et al. 2007; Meyer et al. 2005; Potters et al. 2010).

A large number of Trx proteins have been identified in plants (Meyer et al. 2005; Nuruzzaman et al. 2008). In Arabidopsis thaliana, Trx proteins fall into six major categories, referred to as the Trx h, f, m, o, x, and y multigenic families (Reichheld et al. 2002). Members of different families are predicted to target

L. Sun, H. Ren, R. Liu, and B. Li contributed equally to this work.

Corresponding author: H. Dong; E-mail: hsdong@ njau.edu.cn; Telephone: +862584399006 and +8625 13813928425; Fax: +862584396246. a wide range of proteins and regulate various redox-dependent cellular processes (Gelhaye et al. 2005; Hall et al. 2010; Meyer et al. 2002; Montrichard et al. 2008). The h-type Trx (Trx-h) proteins represent the largest Trx family. They are most complicated in structure and biochemical properties and are believed to be the most multifunctional family in terms of the redox pathways and other cellular processes in which they are involved (Gelhaye et al. 2004a, 2005). However, only a few of these predicted functions have been elucidated for Trx-h proteins (Park et al. 2009).

Their intrinsic biochemical activity enables plant Trx-h proteins to function in the regulation of cellular redox (Atkinson et al. 2009; Blokhina and Fagerstedt 2010; Gelhaye et al. 2004a and b; Serrato and Cejudo 2003; Traverso et al. 2007) and defense responses (Jiang et al. 2010; Kandasamy et al. 2009; Laloi et al. 2004; Sweat and Wolpert 2007). By catalyzing thiol-disulfide interchanges, Trx-h proteins can transfer reducing equivalents (Baumann and Juttner 2002; Dal Piaz et al. 2010; Oliveira et al. 2010; Schurmann and Jacquot 2000) and relieve toxicity of hydrogen peroxide $\left(\mathrm{H}_{2} \mathrm{O}_{2}\right)$ and other reactive oxygen species (ROS) (Blokhina and Fagerstedt 2009), thus protecting plants from damage caused by oxidative stress (Brehelin et al. 2004; Pulido et al. 2009; Serrato and Cejudo 2003; Traverso et al. 2007; Vieira Dos Santos and Rey 2006). Increasing attention has been paid to the role of Trx-h proteins as signaling intermediates beyond their intrinsic antioxidant activities (Bashandy et al. 2010; Dal Piaz et al. 2010; Tada et al. 2008). Owing to their function in regulating cellular redox, Trx-h proteins are thought to play an important role in redoxrelated defensive responses (Kandasamy et al. 2009; Laloi et al. 2004; Sweat and Wolpert 2007). In Arabidopsis, expression of $A t T R X-h 3$ and $A t T R X-h 5$ can be induced by a pathogen and contributes to systemic acquired resistance (SAR) (Laloi et al. 2004; Tada et al. 2008). SAR is induced by the expression of pathogenesis-related (PR) genes via NPR1 protein (Cao et al. 1997; Dong et al. 2001). During the development of SAR, activated AtTRX-h3 and AtTRX-h5 regulate the conformation of NPR1 in the cellular redox environment (Tada et al. 2008). The cellular redox environment is indicated by the glutathione/ glutathione disulfide couple (GSH/GSSG) ratio, which increases with cellular reducing conditions (Schafer and Buettner 2001). AtTRX-h3 and AtTRX-h5 increase reducing equivalents to generate the cellular reducing environment required for the conversion of NPR1 from a nonfunctional dimer or oligomer to a functional monomer (Mou et al. 2003; Tada et al. 2008). 
As a result, PR genes are expressed and SAR develops (Laloi et al. 2004; Tada et al. 2008).

The regulation of NPR1 and SAR by AtTRX-h3 and AtTRXh5 in Arabidopsis provides a paradigm for the functional relationship between Trx-h and defense responses in plants. However, the regulation of NPR1 and subsequent expression of PR genes were characterized in Arabidopsis in response to a bacterial pathogen (Laloi et al. 2004; Tada et al. 2008). There is no evidence to show any roles of NPR1 and PR genes in resistance to viruses, such as Cucumber mosaic virus (CMV) and Tobacco mosaic virus (TMV), investigated in this study. Moreover, little is known about defensive functions of other members of the Trx-h family. Three homologues of the Trx-h gene-NtTRXh1, NtTRXh2, and TRXh-like-have been identified in tobacco. NtTRXh1 and NtTRXh2 transcripts have been shown to accumulate in most types of organs and tissues but have not been implicated in any specific biological processes (Brugidou et al. 1993). Little is known about $T R X h$-like aside from its sequence, which is available in the GenBank database (GenBank accession number AF435818). Whether any of the NtTRXh genes function in tobacco defense responses remains an open question.

The aim of this study was to determine whether the NtTRXh genes function in tobacco defense responses, particularly to paraquat, CMV, and TMV. Paraquat is an herbicide often used as an inducer of plant oxidative stress (Albertsson et al. 2010; Wang et al. 2010). CMV and TMV are pathogenic viruses that are compatible and incompatible, respectively, with NN-genotype tobacco cultivars, which carry the homozygous resistance gene $N$ (Bevan et al. 1985; Culver et al. 1991; Salánki et al. 2004; Whitham et al. 1994; Wisniewski et al. 1990). We found that the expression of $T R X h$-like, but not NtTRXh1 and NtTRXh2, was inducible by paraquat, TMV, and CMV. Therefore, we cloned the coding sequence (CDS) of TRXh-like, expressed the protein using a prokaryotic expression system, and tested its bioactivity in catalysis of a specific thiol-disulfide interchange. Based on the results of these studies, we designated the Trxh-like gene NtTRXh3. Finally, we investigated the effect of overexpressing this gene in transgenic tobacco and silencing it in wild-type (WT) plants to further elucidate the role of NtTRXh3 (NtTRXh3) in tobacco plant responses to virus infection and paraquat-induced oxidative stress.

\section{RESULTS}

$N t T R X h 3$ expression is induced by paraquat and viruses.

To determine whether NtTRXh1, NtTRXh2, and NtTRXh3 (previously $T R X h$-like) are transcribed in response to oxidative stress, we studied the expression of these genes in plants of tobacco cv. Samsun-NN following treatment with paraquat. Gene expression was first determined by semiquantitative reverse-transcriptase polymerase chain reaction (RT-PCR) analysis, using EFI $\alpha$ as a reference gene (Dong et al. 2005; Peng et al. 2003b). Expression levels of the three NtTRXh genes differed greatly in tobacco plants treated with an aqueous paraquat solution compared with pure water (Fig. 1A). Paraquat treatment induced the expression of $N t T R X h 3$, but not NtTRXh1 and NtTRXh2, more than $12 \mathrm{~h}$ posttreatment (hpt). The constitutive expression of NtTRXh3 in water-treated plants from $0 \mathrm{hpt}$ (immediately after treatment) through $12 \mathrm{hpt}$ was low, whereas $N t T R X h 1$ and NtTRXh2 were expressed at higher levels. At $12 \mathrm{hpt}$, the amount of NtTRXh3 transcript increased but NtTRXh1 and NtTRXh2 levels remained the same (Fig. 1A). Next, we determined the expression of three NtTRXh genes in plants inoculated with TMV and CMV. Gene expression in TMV-inoculated plants and CMV-inoculated plants was similar to that of paraquat-treated plants (Fig. 1A). Three $N t T R X h$ transcripts were detected in the upper two leaves, at a distance from the first and second leaves that had been inoculated with TMV or CMV. In both TMV- and CMV-inoculated plants, expression of NtTRXh3 was higher at $12 \mathrm{~h}$ postinoculation (hpi) compared with 0 hpi (immediately after inoculation), whereas the amounts of NtTRXh1 and NtTRXh2 transcripts did not change appreciably over this period.

Gene expression levels were quantified by real-time RTPCR using EF1 $\alpha$ (Gallie et al. 1998) and ACTIN2 as reference genes (Wu et al. 2010). Real-time RT-PCR analyses confirmed that NtTRXh3 expression was induced in plants following treatment with paraquat but not water and following inoculation with TMV or CMV but not mock inoculation with water (Fig. 1B). The amount of NtTRXh3 transcript increased significantly over time after treatment with paraquat and after virus inoculation compared with controls (analysis of variance [ANOVA] test, $P<0.01)$. At $48 \mathrm{~h}, N t T R X 3$ transcript had increased 2.7-, 4.8-, and 5.5-fold in response to paraquat and inoculation with TMV and CMV, respectively (Fig. 1B).

\section{NtTRXh3 catalyzes thiol-disulfide interchanges.}

Based on sequence analysis, the cloned NtTRXh3 gene is predicted to encode a 152-amino acid protein. The predicted
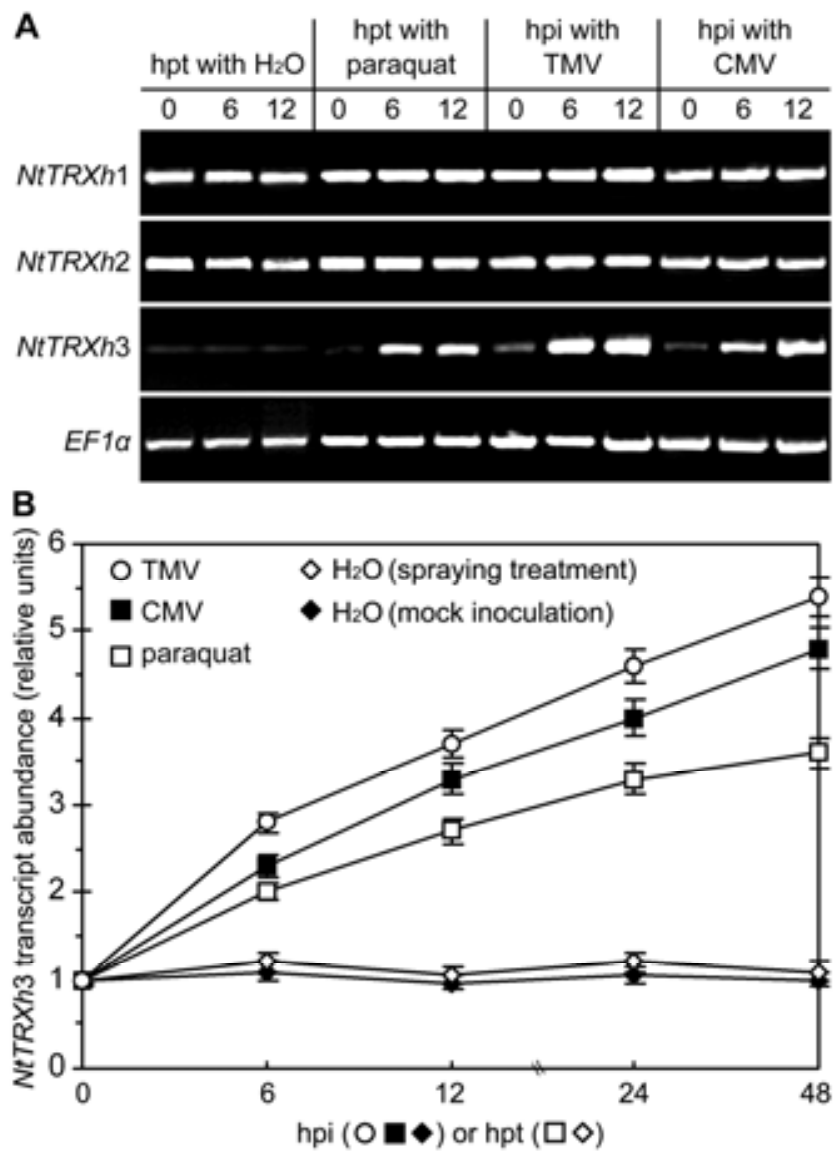

Fig. 1. Expression of three TRXh genes in tobacco. A, Semiquantitative reverse-transcriptase-polymerase chain reaction (RT-PCR) analyses using the $E F 1 \alpha$ gene as a reference. B, Real-time RT-PCR analyses. In A, 30day-old plants were treated by spraying with an aqueous solution of paraquat or pure water as a control. Equivalent plants were inoculated with Tobacco mosaic virus (TMV) or Cucumber mosaic virus (CMV) on the first and second leaves. RNA was isolated from the fourth and fifth leaves at the indicated hour posttreatment (hpt) or hour postinoculation (hpi). In $\mathrm{B}$, experiments were the same as in A except that data from plants mock inoculated with pure water was presented. Transcript abundance at $0 \mathrm{hpt}$ or $0 \mathrm{hpi}$ was defined as 1 to quantify transcript levels. Histograms represent means \pm standard deviation. In A and B, 0 hpt refers to "immediately after treatment" and 0 hpi refers to "immediately after inoculation". 
NtTRXh3 protein is highly similar to several known Trx-h proteins in amino acid sequence, and contains the conserved WC(G/P)PC motif (Fig. 2A). Because this motif characterizes Trx proteins and is essential for catalysis of thiol-disulfide interchanges (Gelhaye et al. 2005), we hypothesized that the NtTRXh3 protein has this catalytic activity. Therefore, we tested the catalytic ability of NtTRXh3 protein produced in a prokaryotic expression system. Full-length NtTRXh3 CDS cloned from tobacco and confirmed by sequencing was fused to a single His tag coding for six tandem histidines (Fig. 2B), which was used to purify the protein by nickel chromatography (Chen et al. 2008). The NtTRXh3::His fusion protein was predicted to be $22.4 \mathrm{kDa}$ in size, comprising the $16.7 \mathrm{kDa}$ of NtTRXh3 protein and the 5.7-kDa His-flanked region from the vector. This prediction was confirmed by gel electrophoresis (Fig. 2C). The resulting fusion protein effectively catalyzed the reduction of insulin disulfides in vitro (Fig. 2D). Because the insulin disulfide reduction occurs through thiol-disulfide interchange (Holmgren 1979), we may regard NtTRXh3 as a redox protein.

\section{Generation of transgenic tobacco}

\section{for inducible $N t T R X h 3$ expression.}

To manipulate NtTRXh3 expression in transgenic tobacco, we used the plant pathogen-inducible promoter PPP1 (Gough et al. 1995; Peng et al. 2003a) to construct the transformation unit. Previously, we showed that the activity of PPP1 is in- duced by harpin group proteins from plant-pathogenic bacteria (Peng et al. 2003a). In this study, we found that NtTRXh3 expression was induced in plants treated with $\mathrm{HrpN}_{\mathrm{Ea}}$ (Fig. 3A, section a), a well-studied harpin protein (Dong et al. 1999, 2004, 2005; Kim and Beer 2000; Peng et al. 2003b, 2004; Ren et al. 2008; Wei et al. 1992; Zhang et al. 2007). PPP1 was fused to the NtTRXh3 CDS to construct the pBI121:: PPP1:: $N t T R X h 3$ vector (Fig. 3A, section b). After transformation with the recombinant vector, 20 transgenic tobacco lines were arbitrarily selected and characterized, along with transgenic control plants generated by transformation with the $\mathrm{pBI} 121$ vector alone. Homozygous T3 progenies were assayed for NtTRXh3 expression induced by $\mathrm{HrpN}_{\mathrm{Ea}}$, which was applied to plants in an aqueous solution. Different tobacco genotypes varied greatly in NtTRXh3 expression (Table 1). All transgenic lines had similar levels of constitutive NtTRXh3 transcription, as observed in water-treated control plants. Of the 20 NtTRXh3expressing lines, 17 were more responsive to the application of $\mathrm{HrpN}_{\mathrm{Ea}}$ than the transgenic control and showed significantly more $\mathrm{HrpN}_{\mathrm{Ea}}$-induced expression of the gene than controls (ANOVA test, $P<0.01$ ). Therefore, these lines were designated as inducible NtTRXh3-overexpression tobacco (TRXOT) plants. The 17 TRXOT lines accumulated greater amounts of NtTRXh3 transcript in response to $\mathrm{HrpN}_{\mathrm{Ea}}$ than to water (Student's $t$ test, $P<0.01)$. The line TRXOT1 had the highest NtTRXh3 expression (Table 1). This line had three copies of the transgene in addition to the single copy of NtTRXh3

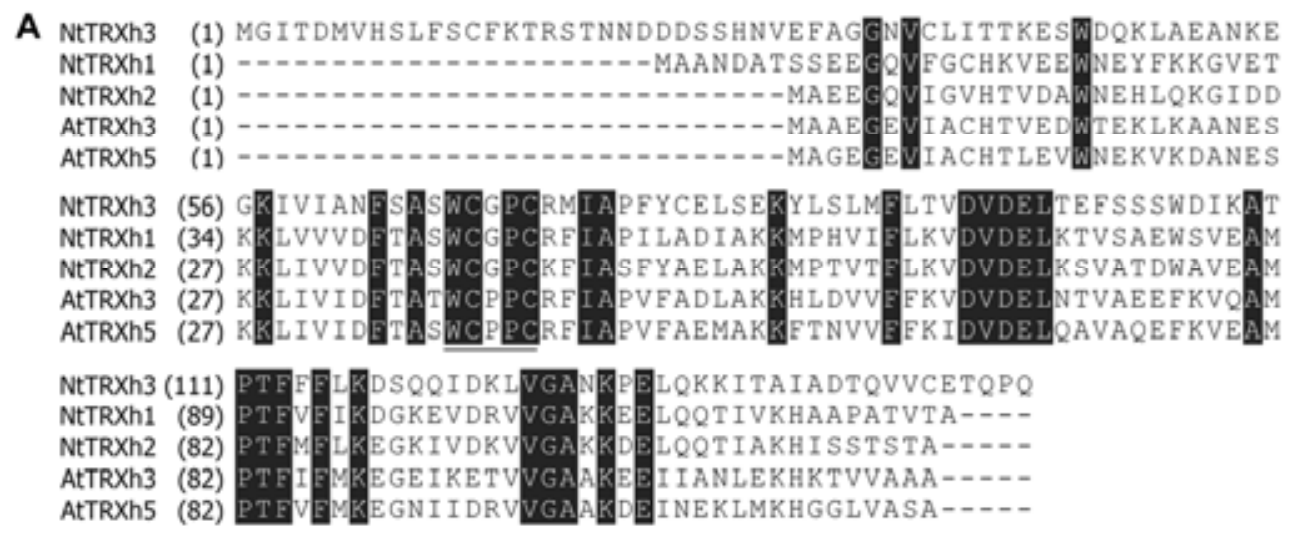

B
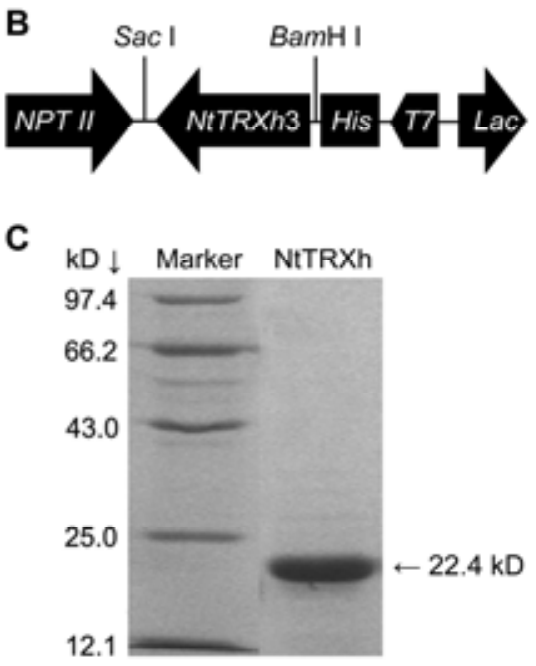

D

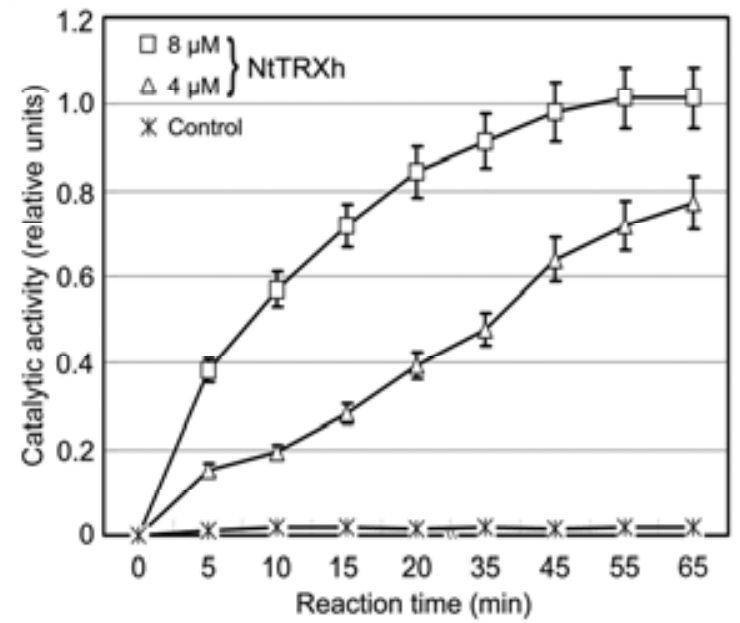

Fig. 2. Characterization of NtTRXh3. A, Sequence alignments of the predicted NtTRXh3 protein and closely related Trx-h homologues. NtTRXh1 (GenBank accession no. CAA41415) and NtTRXh2 (CAA77847) are from tobacco, and AtTRXh3 (NP_199112) and AtTRXh5 (NP_175128) are from Arabidopsis. Identical amino acid residues are highlighted in black boxes. The WCG/PPC motif is underlined. B, Part of the prokaryotic expression vector containing an NtTRXh3 insert. Elements used in this study include the kanamycin-resistance gene (NPT II), histidine (His) tag, T7 promoter (T7), and reporter gene (lac). C, Electrophoresis of purified NtTRXh3 and molecular weight markers. D, Catalytic activity of NtTRXh3 to reduce insulin by dithiothreitol. Control refers to reaction solution without NtTRXh3. Data are shown as mean \pm standard deviation of three experiments. 
already present in the genome (Fig. 3A, section c). The amount of NtTRXh3 transcript was greater in TRXOT1 than in transgenic control plants at each time point over $24 \mathrm{~h}$ after application of $\operatorname{HrpN}_{\mathrm{Ea}}$ (Fig. 3A, section d).

\section{Virus resistance and SAR pathway activation are enhanced in TRXOT1 plants.}

The response to treatment with $\mathrm{HrpN}_{\mathrm{Ea}}$ and inoculation with TMV and CMV were compared in TRXOT1 and transgenic control plants with and without $\mathrm{HrpN}_{\mathrm{Ea}}$, which was applied to the first and second basal leaves 5 days previous to inoculation. Both genotypes responded to infection by viruses inoculated in the fourth and fifth leaves on the top part of the plant. In the absence of $\mathrm{HrpN}_{\mathrm{Ea}}$, TRXOT1 and the transgenic control plant responded similarly to TMV. Both types of tobacco plants incurred similar severities of TMV-induced necrosis symptoms on inoculated local leaves (Fig. 4A), which were equivalent in the number (Fig. 4B) and diameter (Fig. 4C) of necrotic lesions. The application of $\mathrm{HrpN}_{\mathrm{Ea}}$ clearly alleviated TMV-caused necrosis severities in both genotypes (Fig. 4A). Both the number (Fig. 4B) and diameter (Fig. 4C) of necrotic lesions were significantly lower in both TRXOT1 and transgenic control plants treated with $\mathrm{HrpN}_{\mathrm{Ea}}$ compared with those treated with water (Student's $t$ test, $P<0.01$ ). However, the reductions in number and diameter of necrotic lesions in $\mathrm{HrpN}_{\mathrm{Ea}}$-treated TRXOT1 plants were greater than in the transgenic control plants (ANOVA test, $P<0.01$ ). $\mathrm{HrpN}_{\mathrm{Ea}}$ treatment also attenuated infection by CMV inoculated to lower leaves of plants. At 15 days after inoculation, malformation was observed on the top three leaves of CMV-inoculated plants but not in mockinoculated plants (Fig. 4D). The transgenic control plants had more severe malformations than TRXOT1 plants. $\mathrm{HrpN}_{\mathrm{Ea}}$ treatment resulted in alleviation in CMV-induced leaf malformation, and this effect was more pronounced in TRXOT1 than in transgenic control plants. Therefore, although resistance was induced in control and TRXOT1 tobacco plants to control the pathogenicity of these two viruses, the level of induced resistance was higher in plants overexpressing NtTRXh3.

We next asked whether the repression in pathogenicity correlated with a repression in multiplication of TMV and CMV. Viral multiplication in the fifth leaves of plants was assessed immediately and every other day for 7 days after inoculation by determining the expression of viral genes encoding coat proteins (Abel et al. 1986) (Fig. 3B). Relative levels of $T M V C P$ and $C M V C P$ gene expression were estimated by semiquantitative RT-PCR (Fig. 3B, section a) and real-time RT-
A

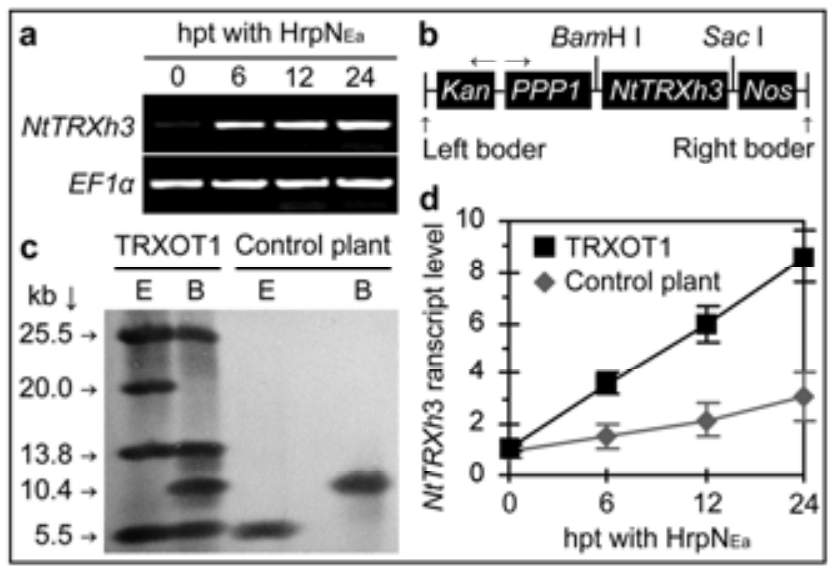

\section{C}

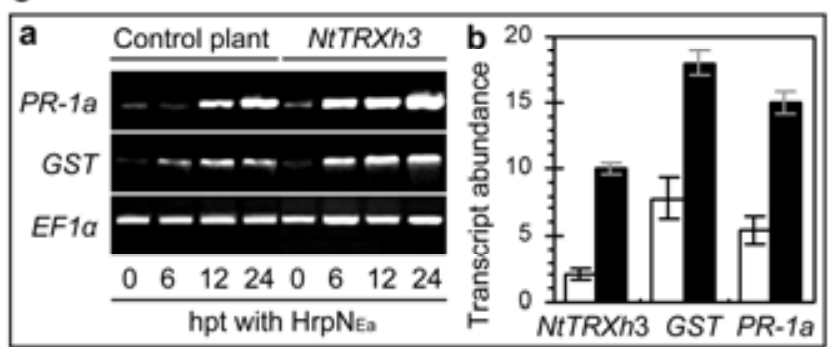

B

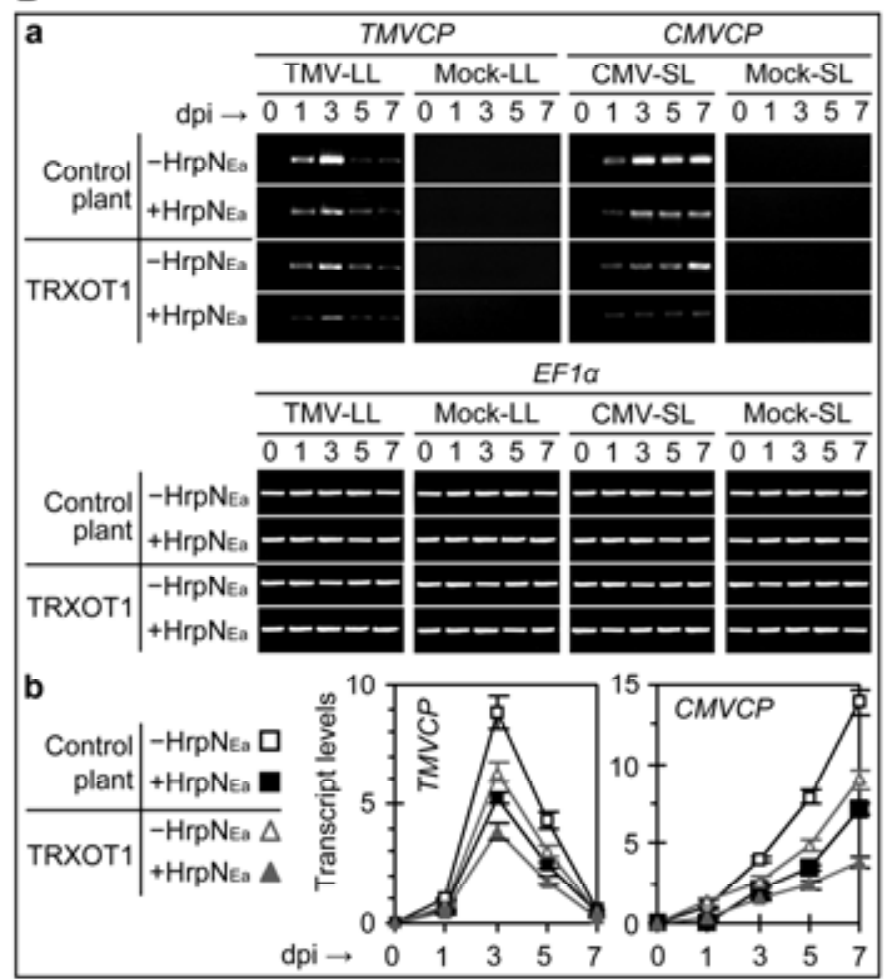

Fig. 3. Manipulation of NtTRXh3 for increased defense responses in tobacco. A, Generation of transgenic plants. Section a, semiquantitative reverse-transcriptase polymerase chain reaction (RT-PCR) analysis of genes expressed in wild-type tobacco. Thirty-day-old plants were treated with HrpN $\mathrm{Ea}_{\mathrm{a}}$, a bacterial harpin protein that elicits the plant defense response, applied to the first and second leaves. For RT-PCR, RNA was isolated from the fourth and fifth (systemic) leaves at the indicated times. Section b, Part of the transformation unit constructed in the pBI121 vector. NtTRXh3 was fused to the HrpN $\mathrm{Ea}^{-i n d u c i b l e}$ plant pathogen-inducible promoter PPP1. LB, left border; Kan, kanamycin-resistance gene; Nos, a transcription terminator; RB, right border. Section c, Southern blot hybridized with the NtTRXh3-specific probe labeled with digoxigenin. Genomic DNA from the NtTRXh3-overexpression tobacco (TRXOT) line 1 (TRXOT1) and from the transgenic control line were digested with EcoRI (E) and BamHI (B). Section d, Real-time RT-PCR analysis of NtTRXh3 transcript from systemic leaves of TRXOT1 and transgenic control plants treated with $\mathrm{HrpN}_{\mathrm{Ea}}$ applied to the first and second leaves. B, Detection of TMVCP and $C M V C P$ genes from plants. Thirty-day-old plants were untreated $\left(\mathrm{HrpN}_{\mathrm{Ea}}\right)$ or treated with $\mathrm{HrpN}_{\mathrm{Ea}}\left(+\mathrm{HrpN}_{\mathrm{Ea}}\right)$. Five days after treatment, the fifth leaves were inoculated with Tobacco mosaic virus (TMV) or Cucumber mosaic virus (CMV), or mock inoculated with water. Section a, semiquantitative RT-PCR was used to detect TMVCP from TMV-inoculated local leaves (TMV-LL) and mock-inoculated local leaves (Mock-LL), and to detect $C M V C P$ from systemic leaves of CMV-inoculated plants (CMV-SL) and mock-inoculated plants (Mock-SL). Section b, Real-time RT-PCR was conducted to detect TMVCP from TMV-inoculated leaves and $C M V C P$ from systemic leaves of CMV-inoculated plants. C, Expression of tobacco defense response genes $P R$ - $1 a$ and glutathione S-transferase (GST). Section a, Semiquantitative RT-PCR analysis of gene expression in systemic leaves of $\mathrm{HrpN}_{\mathrm{Ea}}$-treated plants at the indicated intervals. Section b, Real-time RT-PCR analysis of gene expression at $24 \mathrm{~h}$ posttreatment (hpt). Transcript levels were normalized to $0 \mathrm{hpt}$ levels (1) for quantification at $24 \mathrm{hpt}$. In all experiments, quantitative data are presented as mean \pm standard deviation of three experiments. 
PCR (Fig. 3B, section b), using RNA samples isolated from plant leaves. As an experimental control, RT-PCR using the same RNA samples and primers specific to the tobacco $E F 1 \alpha$ gene showed uniform amplification of the plant gene (Fig. 3B, section a), which indicates the reliability of the method. Because TMV-induced necrosis is characteristic of the hypersensitive response that restricts the virus to the infected tissue in NN-genotype tobacco cultivars (Whitham et al. 1994), the TMVCP gene was studied in both the fourth and TMV-inoculated leaves (Fig. 3B). Noninoculated leaves above the inoculated fifth leaves (Fig. 3B) were used to test for expression of the $C M V C P$ gene (Fig. 4D), because CMV infection is systemic (Culver et al. 1991; Troutman and Fulton 1958).

NtTRXh3 overexpression resulted in a reduced level of the TMVCP transcript. The transcript was detected in TMVinfected fifth leaves of tobacco but not from equivalent leaves mock inoculated with water (Fig. 3B, sections a and b). In TMV-infected local leaves of both genotypes, TMVCP was expressed within 24 hpi. Over the next 2 days, the transcript level increased sharply, and then declined to a low level in the next 4 days. Much smaller amounts of TMVCP transcript were detected in plants treated with $\mathrm{HrpN}_{\mathrm{Ea}}$ prior to inoculation. The inhibitory effect of $\mathrm{HrpN}_{\mathrm{Ea}}$ on TMVCP expression was significant (ANOVA test, $P<0.01$ ) at 1 and 3 days postinoculation. At the same time points, the level of TMVCP expression was much lower in TRXOT1 plants than in transgenic controls (ANOVA test, $P<0.01$ ), regardless of whether plants had been

Table 1. Comparison of transgenic tobacco lines in levels of NtTRXh3 expression

\begin{tabular}{|c|c|c|}
\hline \multirow[b]{2}{*}{ Codes of TRXOT lines } & \multicolumn{2}{|c|}{$\begin{array}{c}\text { Relative levels of } N t T R X h 3 \text { expression } \\
\text { in response to }\end{array}$} \\
\hline & Water & $\operatorname{HrpN}_{\text {Ea }}$ \\
\hline 1 & 0.96 & 8.55 \\
\hline 2 & 1.11 & 8.02 \\
\hline 3 & 1.02 & 7.86 \\
\hline 4 & 0.89 & 7.68 \\
\hline 5 & 0.94 & 7.32 \\
\hline 6 & 0.99 & 7.01 \\
\hline 7 & 1.03 & 6.89 \\
\hline 8 & 1.02 & 6.79 \\
\hline 9 & 0.93 & 6.6 \\
\hline 10 & 1.03 & 6.5 \\
\hline 11 & 1.12 & 5.61 \\
\hline 12 & 0.98 & 4.9 \\
\hline 13 & 0.94 & 4.88 \\
\hline 14 & 0.9 & 4.39 \\
\hline 15 & 0.91 & 4.98 \\
\hline 16 & 1.11 & 3.89 \\
\hline 17 & 1.03 & 3.76 \\
\hline $18 *$ & 0.96 & 2.06 \\
\hline $19 *$ & 1.02 & 2 \\
\hline $20 *$ & 0.99 & 1.95 \\
\hline Transgenic control plant & 1.00 & 2.10 \\
\hline
\end{tabular}

a TRXOT refers to NtTRXh3-overexpression transgenic tobacco. Expression of NtTRXh3 was determined by semiquantitative reverse-transcriptase polymerase chain reaction (RT-PCR) using RNA isolated from untreated leaves of plants $24 \mathrm{~h}$ after treatment with pure water or an aqueous $\mathrm{HrpN}_{\mathrm{Ea}}$ solution. Relative levels of gene expression were determined by quantifying intensities of RT-PCR product bands in gel scanned with a gel documentation system. The level of NtTRXh3 expression in transgenic control plants treated with water was defined as 1 to compare levels of the gene expression in $\mathrm{HrpN}_{\mathrm{Ea}}$-treated plants. Based on analysis of variance tests, all the TRXOT lines, except lines 18 to 20, had greater amounts of NtTRXh3 transcript than the transgenic control plant following treatment with $\mathrm{HrpN}_{\mathrm{Ea}}$. Based on Student's $t$ test, the effect of $\mathrm{HrpN}_{\mathrm{Ea}}$ (compared with water) in eliciting NtTRXh3 expression was greater in each of TRXOT and in control plants. Statistical differences were significant at $P<0.05$ for TRXOT lines indicated by an asterisk and at $P<0.01$ for other TRXOT lines and transgenic control plants. pretreated with $\mathrm{HrpN}_{\mathrm{Ea}}$. Thus, although $\mathrm{HrpN}_{\mathrm{Ea}}$ treatment led to repression of TMVCP expression, the repressive effect was greater in TRXOT1 than in control plants.

$N t T R X h 3$ overexpression also resulted in a reduced level of the $C M V C P$ transcript. The transcript was detected in systemic leaves of tobacco plants that had been inoculated with CMV on the fifth leaves but not in mock-inoculated plants (Fig. 3A, sections a and b). CMVCP transcript was detectable from systemic leaves $24 \mathrm{hpi}$ and increased over the next 6 days. Smaller amounts of $C M V C P$ transcript were detected in the NtTRXh3-expressing plant line TRXOT1 and the transgenic control plant following treatment with $\mathrm{HrpN}_{\text {Ea }}$. The inhibitory effect of $\mathrm{HrpN}_{\mathrm{Ea}}$ on $C M V C P$ was significant (ANOVA test, $P<$ $0.01)$ during 6 days since the first day after plant inoculation. As with TMVCP, the amount of CMVCP transcript in TRXOT1 plants was significantly lower than in control plants (ANOVA test, $P<0.01$ ), with or without $\mathrm{HrpN}_{\mathrm{Ea}}$ pretreatment, indicating that the repressive effect of $\mathrm{HrpN}_{\mathrm{Ea}}$ was greatest in TRXOT1 plants.

To determine whether the repression of viral gene expression was accompanied by the tobacco defense response, we studied expression of $P R-1 a$ and glutathione $S$-transferase $(G S T)$, molecular markers of SAR pathway activation (Takahashi and Nagata 1992; Ryals et al. 1996). PR-1 $a$ and GST were expressed earlier in TRXOT1 than in transgenic control plants following treatment with $\mathrm{HrpN}_{\mathrm{Ea}}$ (Fig. 3C, section a). Within $24 \mathrm{hpt}$, both genes were expressed concomitantly with the expression of NtTRXh3, and higher levels of all three transcripts were accumulated in TRXOT1 plants than in controls (Fig. 3C, section b), suggesting enhancement of the SAR pathway in the presence of overexpressed NtTRXh3.

\section{NtTRXh3 gene silencing impairs plant resistance to virus infection.}

The role of NtTRXh3 in tobacco resistance to TMV and CMV was confirmed by posttranscriptional gene silencing (PTGS) experiments. The PTGS system used in this study was composed of the DNA1 vector and a helper vector constructed with DNA components from the monopartite Begomovirus sp. Tobacco curly shoot virus strain Y35 (Cai et al. 2007; Huang et al. 2009; Wang et al. 2009). The DNA1 vector, containing an NtTRXh3 insert, was used together with the helper vector (Fig. 5A) to inhibit accumulation of the NtTRXh3 transcript in tobacco. Agroinfiltration of WT tobacco resulted in NtTRXh3silenced ( $h 3 \mathrm{RNAi}$ ) plants. These plants showed low levels of $N t T R X h 3$ transcripts following treatment with $\mathrm{HrpN}_{\mathrm{Ea}}$, compared with dramatic accumulation of the transcript in untransformed plants and empty vector-transformed control plants (Fig. 5B). The NtTRXh3-silencing effect was greater than $95 \%$, based on quantification of NtTRXh3 transcript levels from h3RNAi and control plants (Fig. 5C).

Gene silencing increased the pathogenicity of TMV and CMV in plants treated with $\mathrm{HrpN}_{\mathrm{Ea}}$. By 5 days after inoculation, TMVinduced necrosis symptoms were more severe in $h 3 \mathrm{RNAi}$ plants compared with control plants (Fig. 5D, section a). The number (Fig. 5D, section b) and diameter (Fig. 5D, section c) of necrotic lesions were greater on the leaves of $h 3$ RNAi plants than on the leaves of control plants (ANOVA tests, $P<0.01$ ). Moreover, h3RNAi plants had more severe CMV-induced leaf malformations at 15 days after inoculation (Fig. 5E). The enhancement in TMV- and CMV-induced symptoms was consistent with levels of $T M V C P$ and $C M V C P$ expression in these plants. At 3 and 5 days after inoculation, TMVCP and CMVCP transcripts in h3RNAi plants were 2.8- and 3.5-fold higher than in control plants, respectively (Fig. 5G).

The impaired resistance phenotype was consistent with repression of induction of the tobacco defense response genes 
GST and $P R-1 a$. Expression of both genes was lower in $h 3 \mathrm{RNAi}$ plants (Fig. $5 \mathrm{H}$ ). Transcription of GST and $P R-1 a$ genes decreased by approximately 65 and $80 \%$, respectively, in $h 3 \mathrm{RNAi}$ plants compared with control plants (ANOVA test, $P<0.01$ ). These results suggest that the plant defense response was partially compromised due to NtTRXh3 silencing, confirming the role of NtTRXh3 in the activation of the SAR pathway.

\section{$N t T R X h 3$ affects the defense response}

\section{to paraquat-induced oxidative stress.}

Oxidative stress has often been induced through paraquat toxicity (Iturbe-Ormaetxe et al. 1998; Murgia et al. 2004). Paraquat toxicity causes necrosis of leaves, and older leaves are more sensitive than younger leaves (Donahue et al. 1997). Several Trx-h genes have been shown to be required for defense responses that coordinate with the alleviation of oxidative stress in plants (Laloi et al. 2004; Serrato and Cejudo 2003; Traverso et al. 2007) but it is unclear whether NtTRXh3 is also involved in the oxidative stress response in tobacco. We addressed the question by comparing the responses of TRXOT1 and transgenic control plants, as well as h3RNAi and WT plants, to paraquat.

TRXOT1 and transgenic control plants were pretreated with an $\mathrm{HrpN}_{\mathrm{Ea}}$ solution applied by spraying the second and third leaves. Six hours later, aerial parts of $\mathrm{HrpN}_{\mathrm{Ea}}$-treated plants were sprayed with a solution of paraquat, because we had found that NtTRXh3 expression was induced by $6 \mathrm{hpt}$ (Fig. 1A). Plants showed paraquat toxicity by $12 \mathrm{hpt}$. During this period, severe toxicity symptoms, such as necrosis of leaves, were observed in transgenic control plants but not in TRXOT1 plants (Fig. 6A). Next, whole $h 3 \mathrm{RNAi}$ and WT plants were treated with paraquat alone. By $12 \mathrm{hpt}$, paraquat toxicity and damage to leaves were seen in both genotypes but the symptoms were much less severe in WT than in h3RNAi (Fig. 6B). In both sets of experiments, paraquat toxicity and damage was seen earlier in older leaves than younger leaves (Fig. 6A and B).
A Transgenic control plant

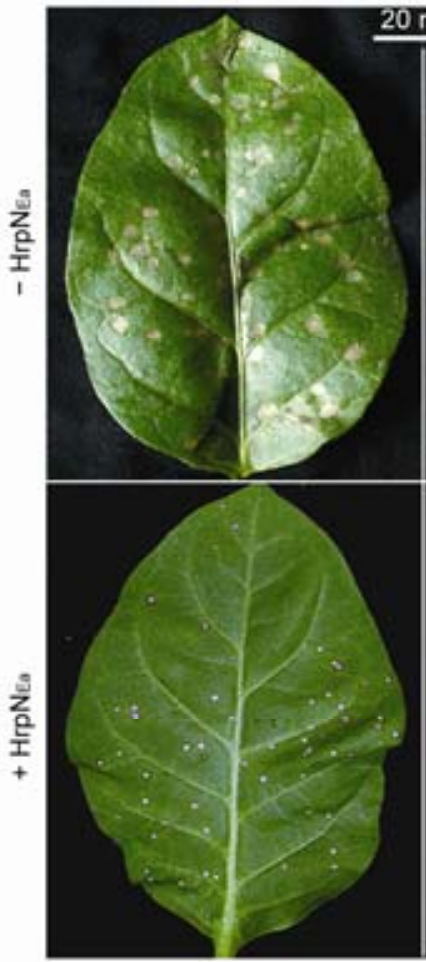

B

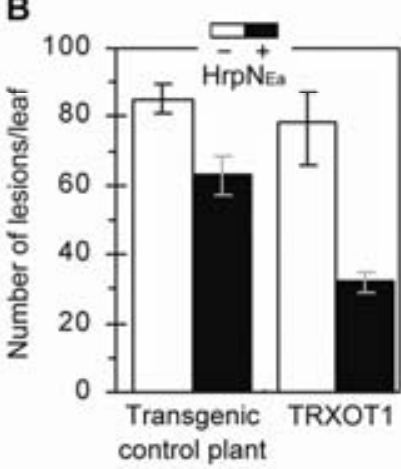

TRXHOT1

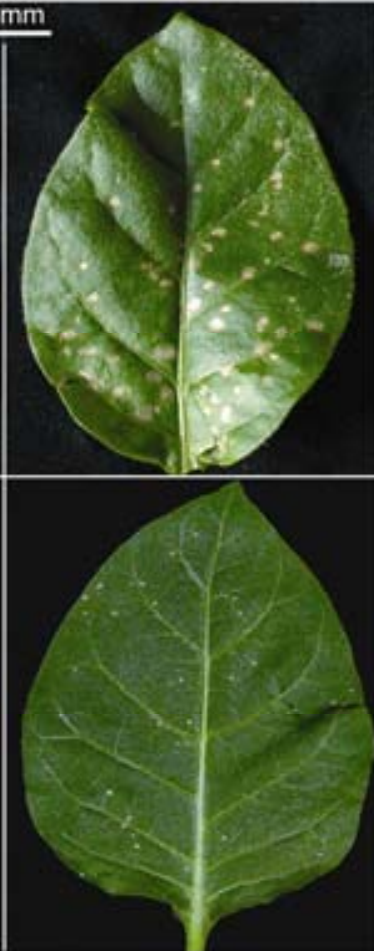

C

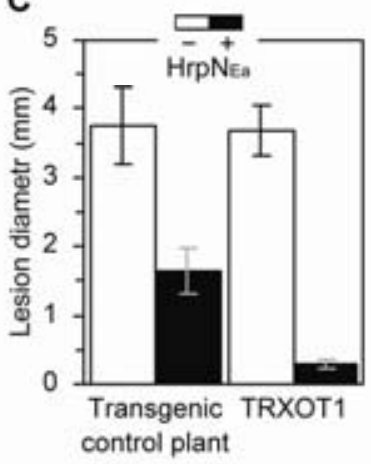

D
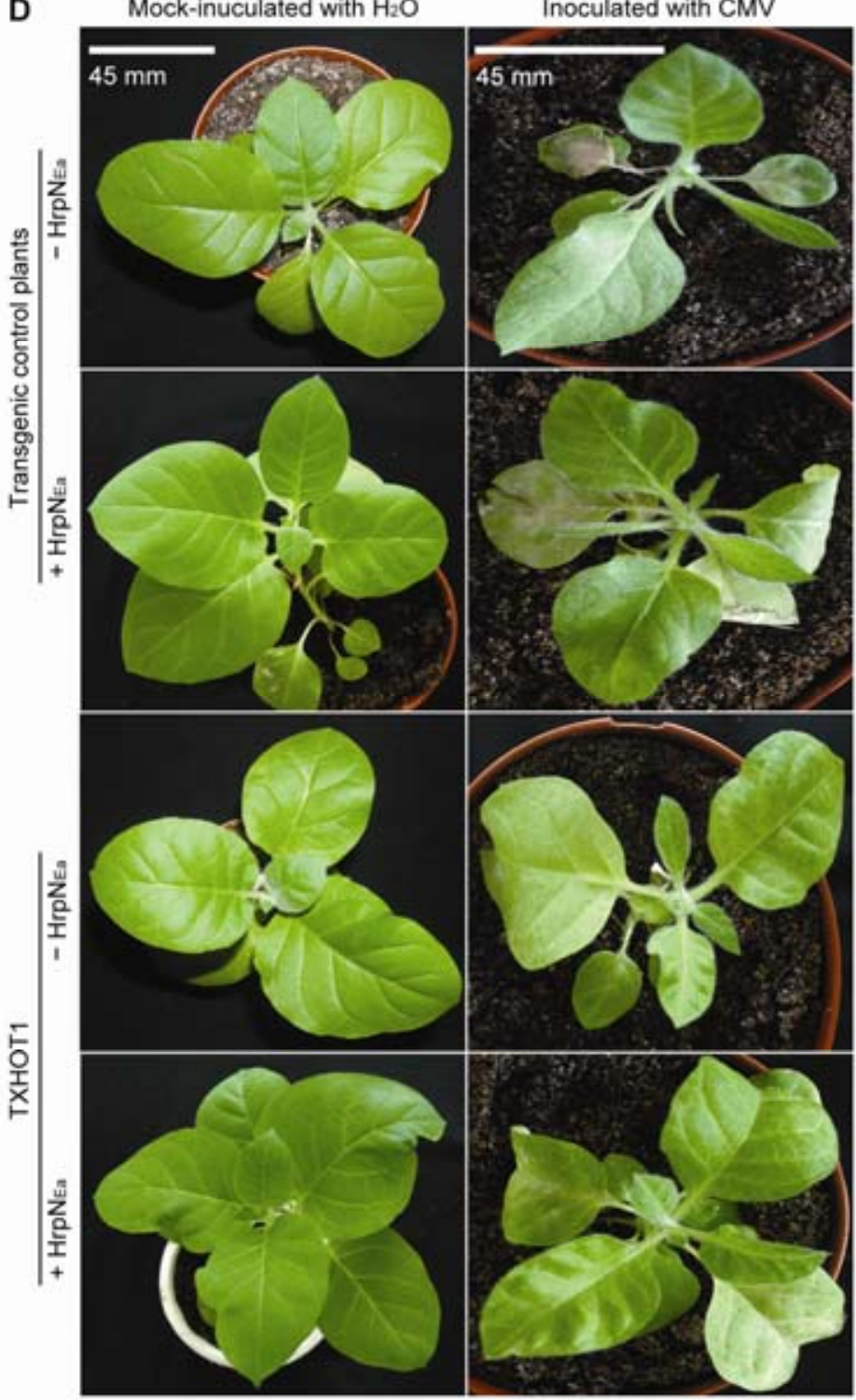

Fig. 4. Plant infection by Tobacco mosaic virus (TMV) and Cucumber mosaic virus $(\mathrm{CMV})$. Plants were treated with $\mathrm{HrpN}_{\mathrm{Ea}}\left(+\mathrm{HrpN}_{\mathrm{Ea}}\right)$ or water $\left(\mathrm{HrpN} \mathrm{N}_{\mathrm{Ea}}\right) 5$ days before inoculation. A through C, Monitoring of plant infection by TMV. Thirty-day-old plants were inoculated and the fourth leaves were photographed at 7 days. These leaves were also investigated to quantify TMV-induced necrotic lesions. Water was used in mock inoculation and did not cause any symptoms (not shown). The scale bar in A applies to all photos. B and C, Data are mean \pm standard deviation of three experiments. D, Monitoring of plant infection by CMV. Twenty-day-old plants were inoculated or mock inoculated and plants were photographed 15 days later. Degree of infection was shown as differences in CMV-caused deformation of top three leaves. Scale bar applies to the vertical photo panel. 
Paraquat toxicity is attributed to excessive generation of ROS and subsequent oxidative stress in plants (Kopyra and Gwozdz 2003; Preston et al. 1992). ROS accumulation was observed by the dichlorofluorescin diacetate (DCFH-DA) luminescence assay, in which ROS are visualized as green fluorescence in plant tissues (Govrin and Levine 2000; Liu et al. 2001). ROS accumulation in TRXOT1 plants was much lower than in transgenic control plants (Fig. 6C). In the controls, high levels of ROS were induced over $12 \mathrm{hpt}$ with paraquat (18 hpt with $\mathrm{HrpN}_{\mathrm{Ea}}$ ), in contrast to low levels of ROS detected at $0 \mathrm{hpt}$ with paraquat (6 hpt with $\mathrm{HrpN}_{\mathrm{Ea}}$ ). During the same period, ROS levels did not increase but, instead, slightly decreased in TRXOT1 plants. In addition to total ROS, levels of $\mathrm{H}_{2} \mathrm{O}_{2}$, an important type of ROS (Torres et al. 2006), were also investigated (Fig. 7A and B). After $12 \mathrm{hpt}$ with para- quat, the amount of $\mathrm{H}_{2} \mathrm{O}_{2}$ was 2.2-fold higher in transgenic control plants than in TRXOT1 plants (Fig. 7A). Similar assays were performed to compare $h 3 \mathrm{RNAi}$ and WT plants in response to paraquat treatment. Over $12 \mathrm{hpt}, \mathrm{h} 3 \mathrm{RNAi}$ plants accumulated total ROS to a greater extent than WT plants (Fig. 6D) and showed twofold more $\mathrm{H}_{2} \mathrm{O}_{2}$ accumulation (Fig. 7B). These data indicate that NtTRXh3 is a key player in ROS scavenging.

The scavenging of ROS was accompanied by expression of $T P R X$, a tobacco gene that encodes thioredoxin peroxidase, which is involved in the oxidative stress response (Dietz 2003; Horling et al. 2001). We determined the expression of TPRX in the four genotypes of tobacco following treatment with paraquat. By $12 \mathrm{hpt}$, the expression of TPRX was induced in all genotypes except $h 3 R N A i$ (Fig. 7C). TPRX transcript was 5.5-fold higher in TRXOT1, 2.2-fold higher in transgenic
A

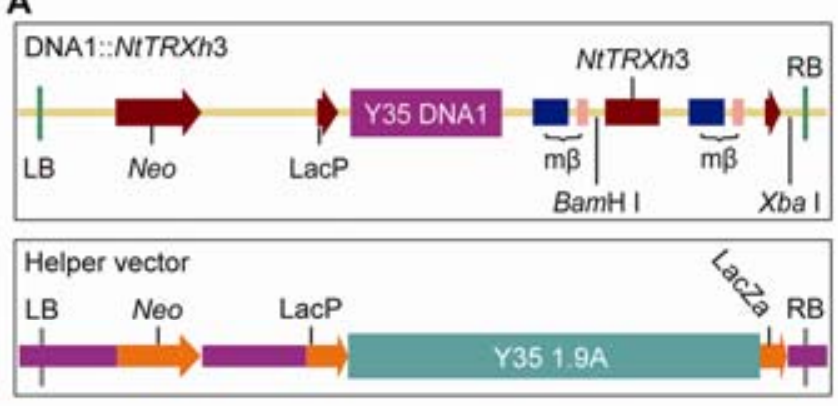

D

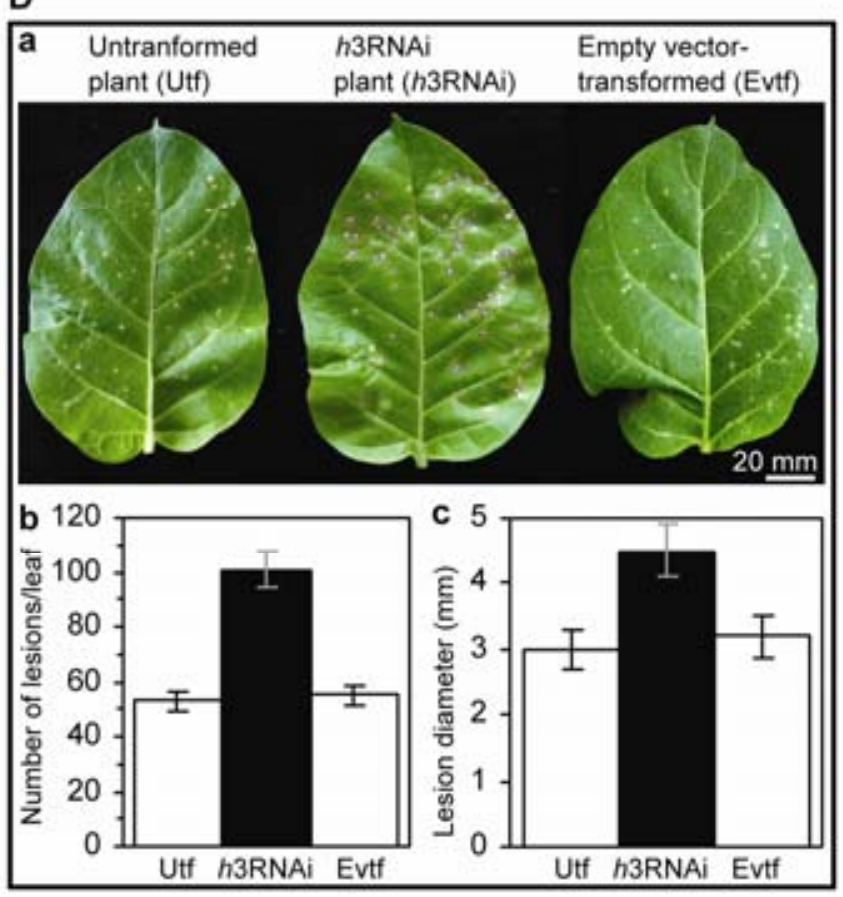

B
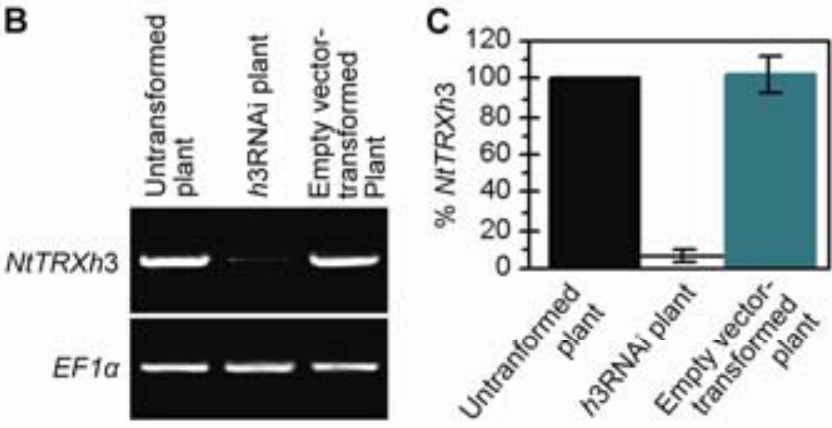

E
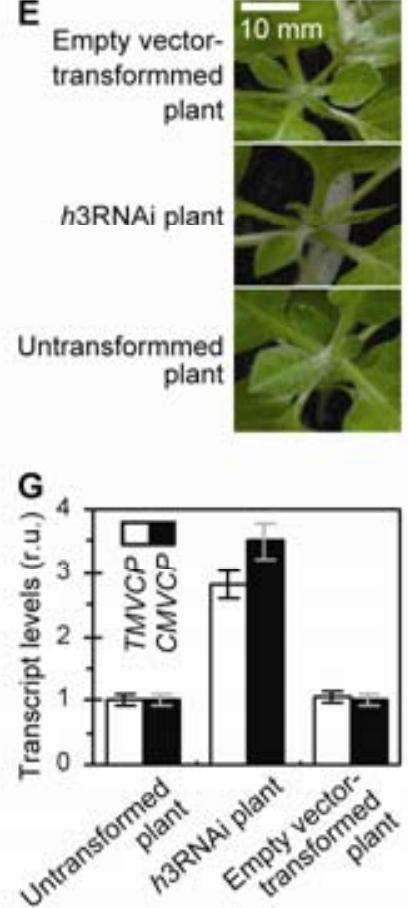
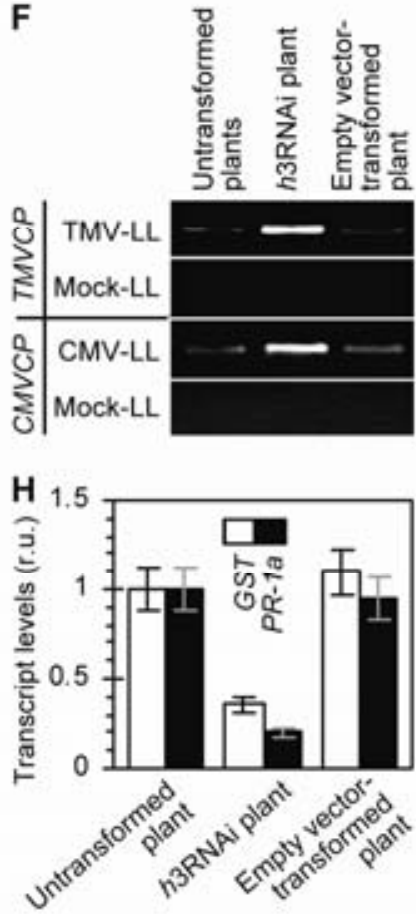

Fig. 5. Effects of NtTRXh3 silencing on tobacco resistance. A, Diagrams of the recombinant DNA1::NtTRXh3 vector and the helper vector. Elements used here include the neomycin-resistance gene Neo, restriction enzymes, the promoter LacP, and the selective marker LacZa. B and $\mathbf{C}$, Gene expression in NtTRXh3-silenced ( $h 3 \mathrm{RNAi}$ ) plants and the two of control plants, 2 days after treatment with $\mathrm{HrpN}_{\text {Ea }}$. In B, semiquantitative reverse-transcriptase polymerase chain reaction (RT-PCR) was performed using EF1 $\alpha$ as a reference gene. In C, real-time RT-PCR was used to quantify the transcript level as $100 \%$ in untransformed plants. D, section a, Appearance of Tobacco mosaic virus (TMV)-induced necrosis on leaves and sections b and c, scoring of necrotic lesions on the fourth leaves. Plants (25 days old) were treated with $\mathrm{HrpN}_{\mathrm{Ea}}$, followed by inoculation 5 days later. Plants were investigated 7 days postinoculation

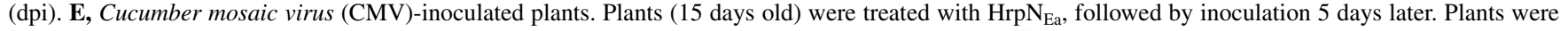
investigated 15 dpi. Mock inoculation with water did not cause any symptoms (not shown). F and $\mathbf{G}$, Detection of viral genes from plants that had been treated with $\mathrm{HrpN}_{\mathrm{Ea}} 5$ days prior to inoculation. In F, semiquantitative RT-PCR was used to detect TMVCP from TMV-inoculated local leaves (TMV-LL) and mock-inoculated local leaves (Mock-LL) at $1 \mathrm{dpi}$, and to detect $C M V C P$ from systemic leaves of CMV-inoculated plants (CMV-SL) and systemic leaves of mock-inoculated plants (Mock-SL) at 5 dpi. In G, real-time RT-PCR was conducted to quantify the TMVCP transcripts from TMV-inoculated leaves 3 dpi and to quantify the CMVCP transcripts from systemic leaves of CMV-inoculated plants 5 dpi. H, Real-time RT-PCR analysis of tobacco gene expression at 24 h posttreatment (hpt) with $\mathrm{HrpN}_{\mathrm{Ea}}$. Transcript levels at $0 \mathrm{hpt}$ were assigned as 1 to quantify transcripts accumulated in 24 hpt. In $\mathrm{D}$, $\mathrm{C}$, $\mathrm{G}$, and $\mathrm{H}$, data are shown as mean \pm standard deviation of three experiments. 
controls, and 2.6-fold higher in WT plants at 12 than at $0 \mathrm{hpt}$ (Fig. 7D). In contrast, induction of TPRX was apparently abrogated in $h 3$ RNAi plants (Fig. 7C) because amounts of the transcript at both 0 and $12 \mathrm{hpt}$ were similar to WT at $0 \mathrm{hpt}$ (Fig. 7D).

\section{The NtTRXh3 protein localizes to chloroplasts} and contributes to cellular reducing conditions.

It has been shown that paraquat causes oxidative stress by inhibiting the production of reducing equivalents from chloroplasts during photosynthesis (Kopyra and Gwozdz 2003; Preston et al. 1992). Evidence also suggests that subcellular localization of Trx proteins is important for their function in particular processes (Gelhaye et al. 2004a, 2005; Hall et al. 2010). Therefore, we examined whether the role of NtTRXh3 in alleviating paraquat toxicity is correlated with the subcellular localization of the protein. In an immunolocalization assay using anti-NtTRXh3 antibody, NtTRXh3 was found to localize exclusively to the chloroplasts of TRXOT1 and transgenic control plants following treatment with $\mathrm{HrpN}_{\mathrm{Ea}}$ (Fig. 8). The relative amount of NtTRXh3 detected in chloroplasts was almost four times higher in TRXOT1 than in transgenic control plants (Fig. 9A). Western blotting was performed with anti-NtTRXh3 antibody to probe for NtTRXh3 isolated from the different genotypes of tobacco at $12 \mathrm{hpt}$ with $\mathrm{HrpN}_{\mathrm{Ea}}$ (Fig. 9B). NtTRXh3 was detected in protein samples from WT, TRXOT1, and transgenic control plants but was absent in samples from $h 3$ RNAi plants. The same amounts of proteins by plant weight were loaded, and the amount of detected NtTRXh3 from TRXOT1 plants was much greater than those from control and WT plants. The protein from $h 3 \mathrm{RNAi}$, if any in the blot, was lower than the limit of detection (Fig. 9B).

The differences in the amounts of NtTRXh3 from the various tobacco genotypes are consistent with a function of $N t T R X h 3$ in reducing paraquat toxicity and ROS generation. ROS depletion is associated with an increase in reducing equivalents, which is critical for the maintenance of cellular reducing conditions (Baumann and Juttner 2002; Lemaire et al. 2007; Vieira Dos Santos and Rey 2006). To examine whether NtTRXh3 contributes to cellular reducing conditions, we compared the GSH/GSSG ratio, which increases with cellular reducing conditions (May et al. 1998; Schafer and Buettner 2001). The GSH/GSSG ratio differed across plant genotypes in response to $\mathrm{HrpN}_{\mathrm{Ea}}$ treatment (Fig. 9C). The ratio increased greatly in TRXOT1, WT, and transgenic control plants at 12 compared with 0 hpt but remained similar in $h 3 \mathrm{RNAi}$ plants over the same period. In TRXOT1 plants, the GSH/GSSG ratio was twofold higher than control plants at $12 \mathrm{hpt}$, suggesting a
A
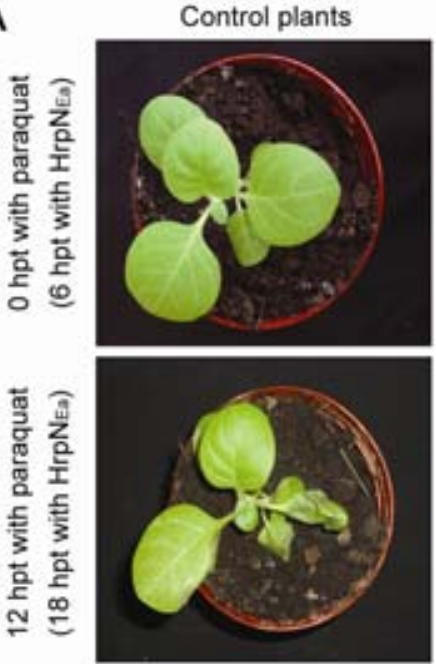

C
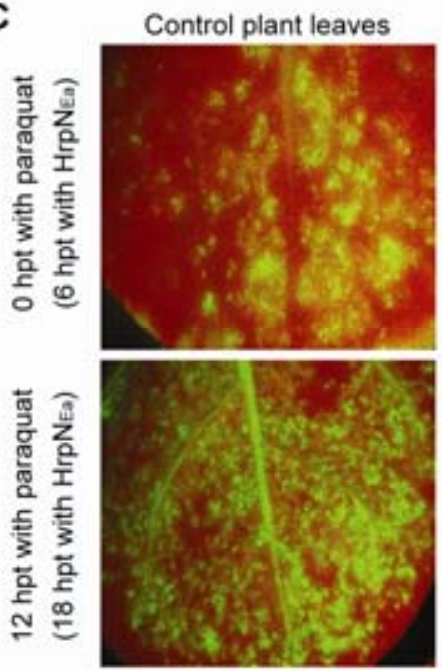
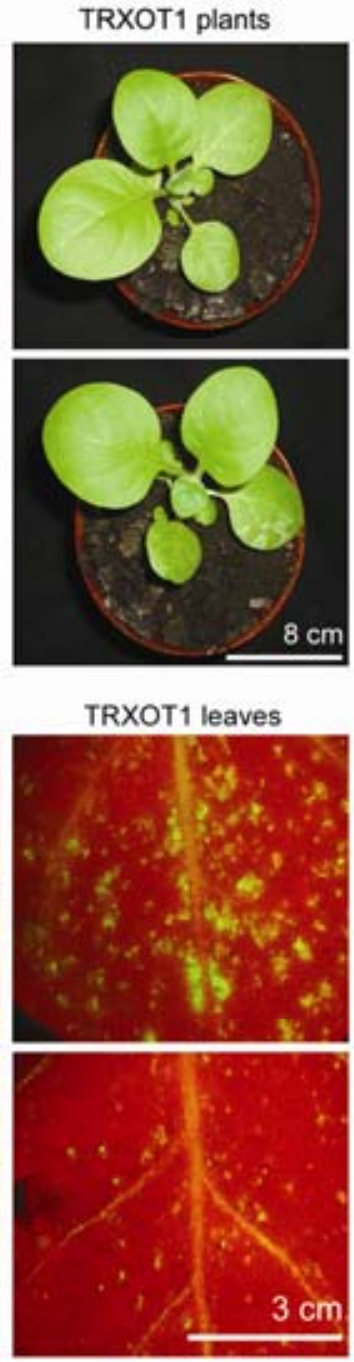

B

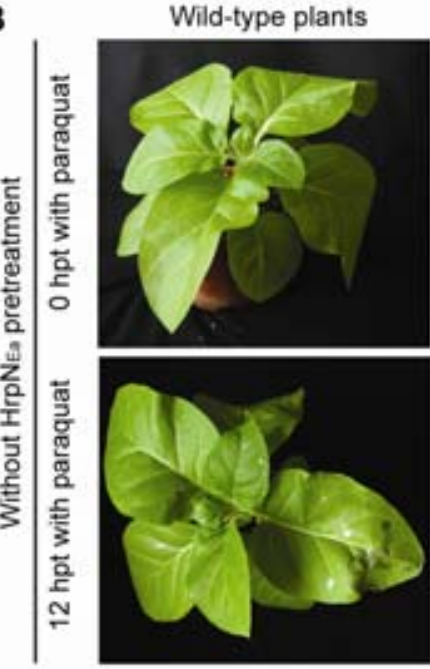

D
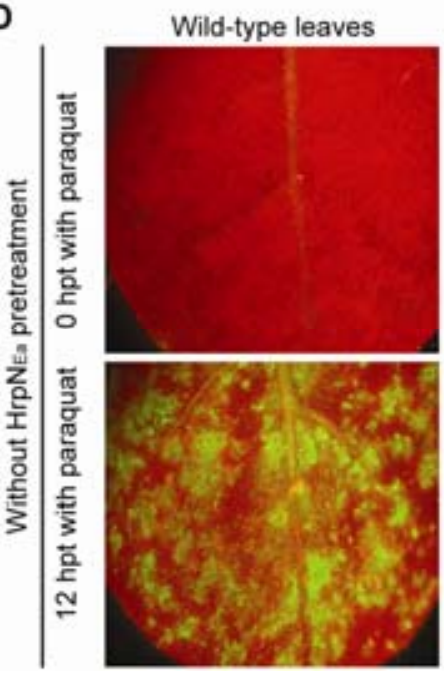

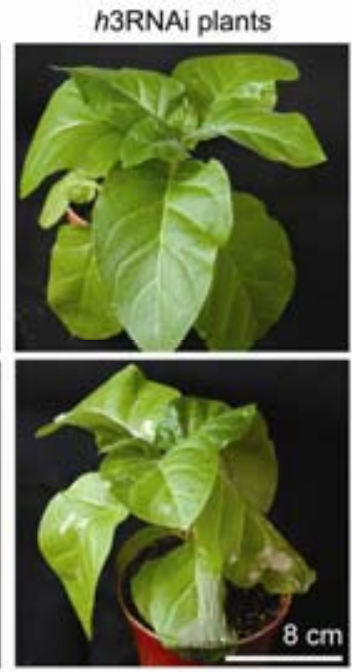

h3RNAi leaves

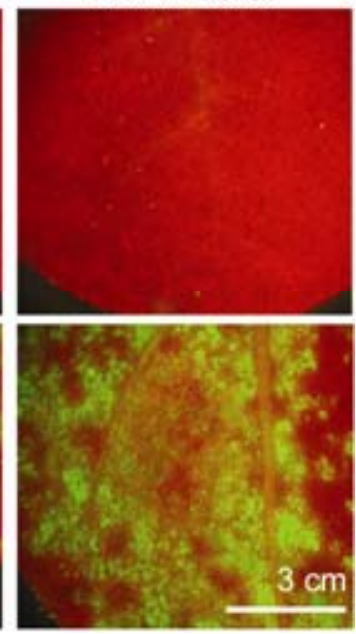

Fig. 6. Paraquat toxicity and reactive oxygen species (ROS) accumulation in TRXOT1, h3RNAi, and control plants. A and B, Paraquat toxicity in transgenic control plants and TRXOT1. Treatments indicated in left vertical panels were applied to 30-day-old TRXOT1 and transgenic control plants and to 45-day-old wild-type and h3RNAi plants. C and D, ROS was visualized by staining leaves with dichlorofluorescin diacetate, a red dye that emits green fluorescence when oxidized by ROS from the leaves. In A through C, scale bar applies to the corresponding panel. 
key contribution of NtTRXh3 to maintaining cellular reducing conditions.

\section{$N t T R X h 3$ gene expression and NtTRXh3 protein production} correlate with defense responses.

To correlate the amount of NtTRXh3 gene transcription and NtTRXh3 protein production with the degree of tobacco defense responses, three TRXOT lines (TRXOT1, TRXOT11, and TRXOT17), which showed high, moderate, and low levels, respectively, of $\mathrm{HrpN}_{\mathrm{Ea}}$-induced NtTRXh3 expression, were compared with WT, transgenic control, and the $h 3 \mathrm{RNAi}$ plants (Fig. 10A; Table 1). Like NtTRXh3, PR-la also showed high, moderate, and low expression in TRXOT1, TRXOT11, and TRXOT17, respectively, following treatment with $\mathrm{HrpN}_{\mathrm{Ea}}$ (Fig. 10A). Transcription levels of NtTRXh3 and $P R-1 a$ genes were much higher in TRXOT1 than in TRXOT11 and TRXOT17 plants, though all the TRXOT plants showed higher levels of transcription than transgenic control and WT plants (Fig. 10A). In contrast, $P R-1 a$ gene expression was almost eliminated in $h 3$ RNAi plants (Fig. 10A).

The NtTRXh3 protein was investigated by Western blot of protein samples from $2 \mathrm{~g}$ of leaves from the different tobacco genotypes (Fig. 10B). By quantifying the levels of NtTRXh3 using a gel documentation system, we found that the protein levels changed similarly to the levels of NtTRXh3 transcripts (Fig. 10B). At least 26, 16, and 10 times more NtTRXh3 was detected from TRXOT1, TRXOT11, and TRXOT17 plants, respectively, than from WT and the transgenic control plants, whereas the protein was almost undetectable in $h 3 \mathrm{RNAi}$ plants. These variations in NtTRXh3 content were reflected by differences in insulin disulfide reduction catalyzed by
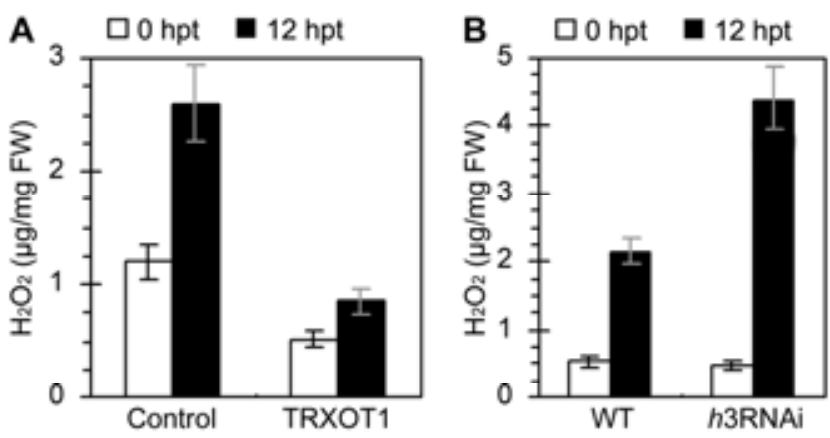

C
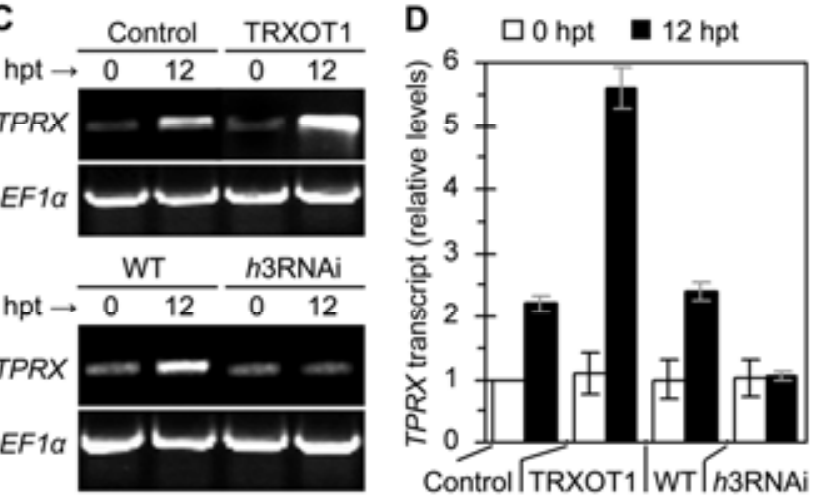

Fig. 7. $\mathrm{H}_{2} \mathrm{O}_{2}$ content and expression of the oxidative stress response gene $T P R X$. Plants were treated with paraquat and the fourth and fifth leaves of treated plants were excised at 0 and $12 \mathrm{~h}$ posttreatment (hpt) to determine $\mathbf{A}$ and $\mathbf{B}, \mathrm{H}_{2} \mathrm{O}_{2}$ content and $\mathbf{C}$ and $\mathbf{D}$, gene expression. In $\mathrm{A}$ and $\mathrm{B}, \mathrm{H}_{2} \mathrm{O}_{2}$ was quantified versus fresh weight $(\mathrm{FW})$ of leaves. In $\mathrm{C}$, reversetranscriptase polymerase chain reaction was performed using EF1 $\alpha$ as a reference gene. In $\mathrm{D}$, comparison was based on defining the transcript level as 1 in the transgenic control plant (control). In A, B, and D, histogram error bars represent standard deviation.
NtTRXh3 protein samples from $2 \mathrm{~g}$ of leaves of the different genotypes (Fig. 10C). Much greater catalytic activity was seen in samples from TRXOT plants than from transgenic control and WT plants, and h3RNAi samples showed only weak catalytic activity.

The relative levels of $\mathrm{H}_{2} \mathrm{O}_{2}$ and total ROS were also lower in genotypes with greater amounts of NtTRXh3 transcript and NtTRXh3 protein (Fig. 10D). Conversely, the GSH/GSSG ratio was elevated to a greater extent in the genotypes that had the highest levels of NtTRXh3 and NtTRXh3 (Fig. 10E). Thus,
Control plant leaf section

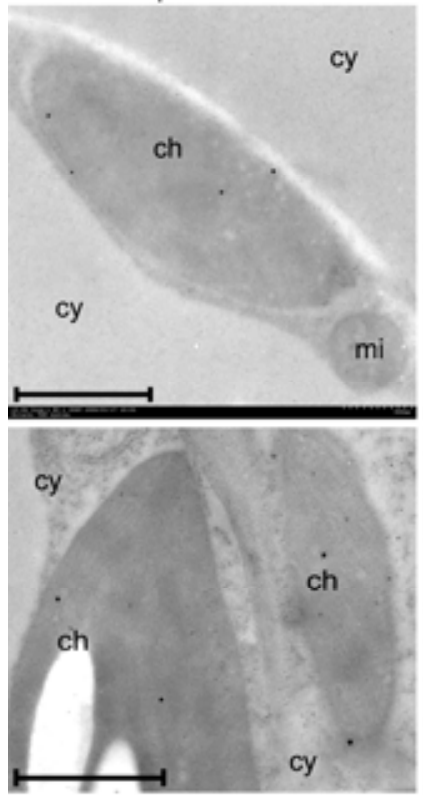

TRXOT1 leaf section

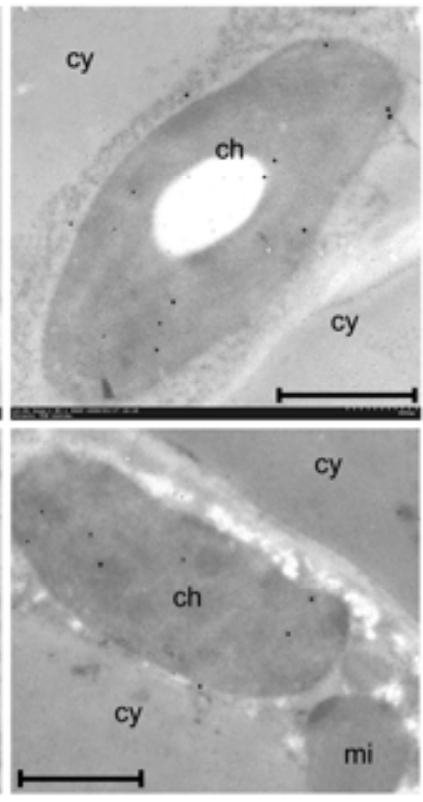

Fig. 8. Immunolocalization of the NtTRXh3 protein. The first and second basal leaves of 30-day-old transgenic control and TRXOT1 plants were treated with $\mathrm{HrpN}_{\mathrm{Ea}}$. Two days later, sections were prepared from the fourth leaves, probed with the colloidal gold and anti-NtTRXh3 antibody complex, and observed by transmission electron microscopy. Scale bar $=1$ $\mu \mathrm{m}$; ch, chloroplast; cy, cytoplasm; mi, mitochondrion.
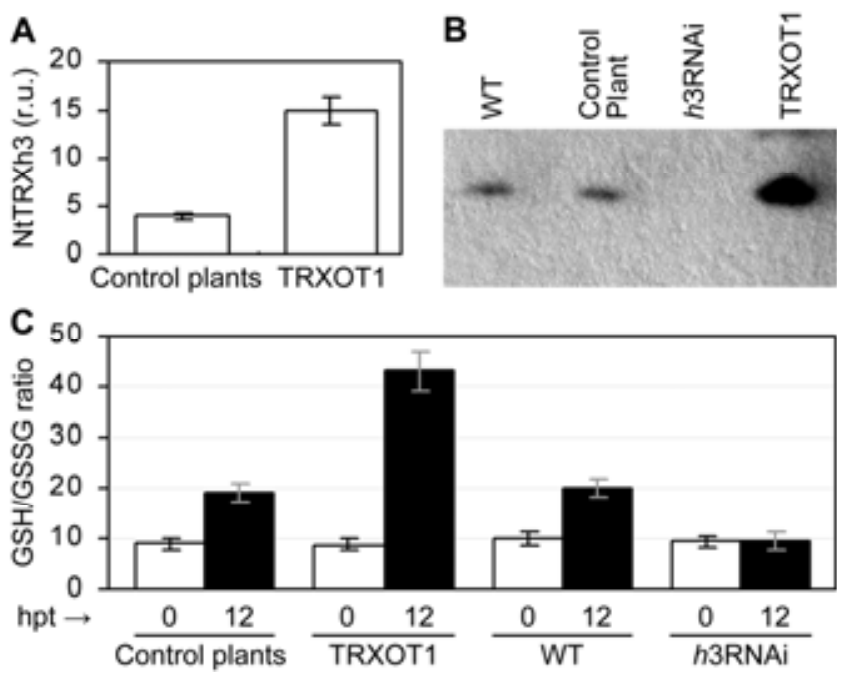

Fig. 9. NtTRXh3 content and glutathione/glutathione disulfide couple (GSH/GSSG) ratio in 30-day-old tobacco plants. A, Relative unit (r.u.) of NtTRXh3 content scored as the number of immune particles per chloroplast. B, Western blot of proteins isolated from fourth leaves and probed with anti-NtTRXh3 antibody. C, GSH/GSSG ratio from plants treated with $\mathrm{HrpN}_{\mathrm{Ea}}$. In A and $\mathrm{C}$, histogram error bars indicate standard deviation. 
greater amounts of transcript and protein correlate with lower ROS levels and the maintenance of cellular reducing conditions. This mechanistic relationship had substantial effects on tobacco resistance to virus infection and paraquat-induced oxidative stress. In the genotypes that had greater amounts of NtTRXh3 transcript and NtTRXh3 protein, lower ROS levels, and higher GSH/GSSH ratios, resistance to paraquat-induced oxidative stress and to TMV infection showed corresponding increases (Fig. 10F). Statistical analyses indicate that TRXOT plants differed significantly from the other genotypes in the extent of all defense responses examined (ANOVA test, $P<$ $0.01)$.

\section{DISCUSSION}

Trx-h represents the most pleiotropic family of Trx proteins proposed to participate in a wide range of metabolic, growth, development, and defense processes in plants (Alkhalfioui et al. 2007; Gelhaye et al. 2004a, 2005; Jiang et al. 2010; Laloi et al. 2004). Various proteins have been suggested as targets of Trx-h, implying that Trx-h proteins may regulate distinct cellular processes (Bower et al. 1996; Gelhaye et al. 2005; Marchand et al. 2004; Montrichard et al. 2008). However, only a few functions (mainly associated with intrinsic redox activity) have been determined for a limited number of plant Trx-h proteins (Meyer et al. 2005; Park et al. 2009; Tada et al. 2008). None of putative tobacco Trx-h genes identified years ago (Brugidou et al. 1993) have yet been examined for redox activity or correlated with particular cellular processes. In particular, little was known about NtTRXh3 beyond its sequence. In this study, we have used molecular, biochemical, and transgenic techniques to investigate the important role of NtTRXh3 in tobacco defense responses to infection by two species of plant-pathogenic viruses, as well as to abiotic oxidative stress.

We first tested whether expression of previously identified tobacco Trx-h genes were affected by inoculation with TMV and $\mathrm{CMV}$, or to treatment with paraquat, a herbicide that induces cellular ROS (Murgia et al. 2004) and causes oxidative damage (Donahue et al. 1997; Kopyra and Gwozdz 2003; Preston et al. 1992). The expression of NtTRXh3 was found to be inducible by TMV, CMV, and paraquat (Fig. 1), suggesting that the gene is likely to participate in tobacco defenses common to virus infection and abiotic oxidative stress. Furthermore, the NtTRXh3 protein effectively catalyzed insulin disul-
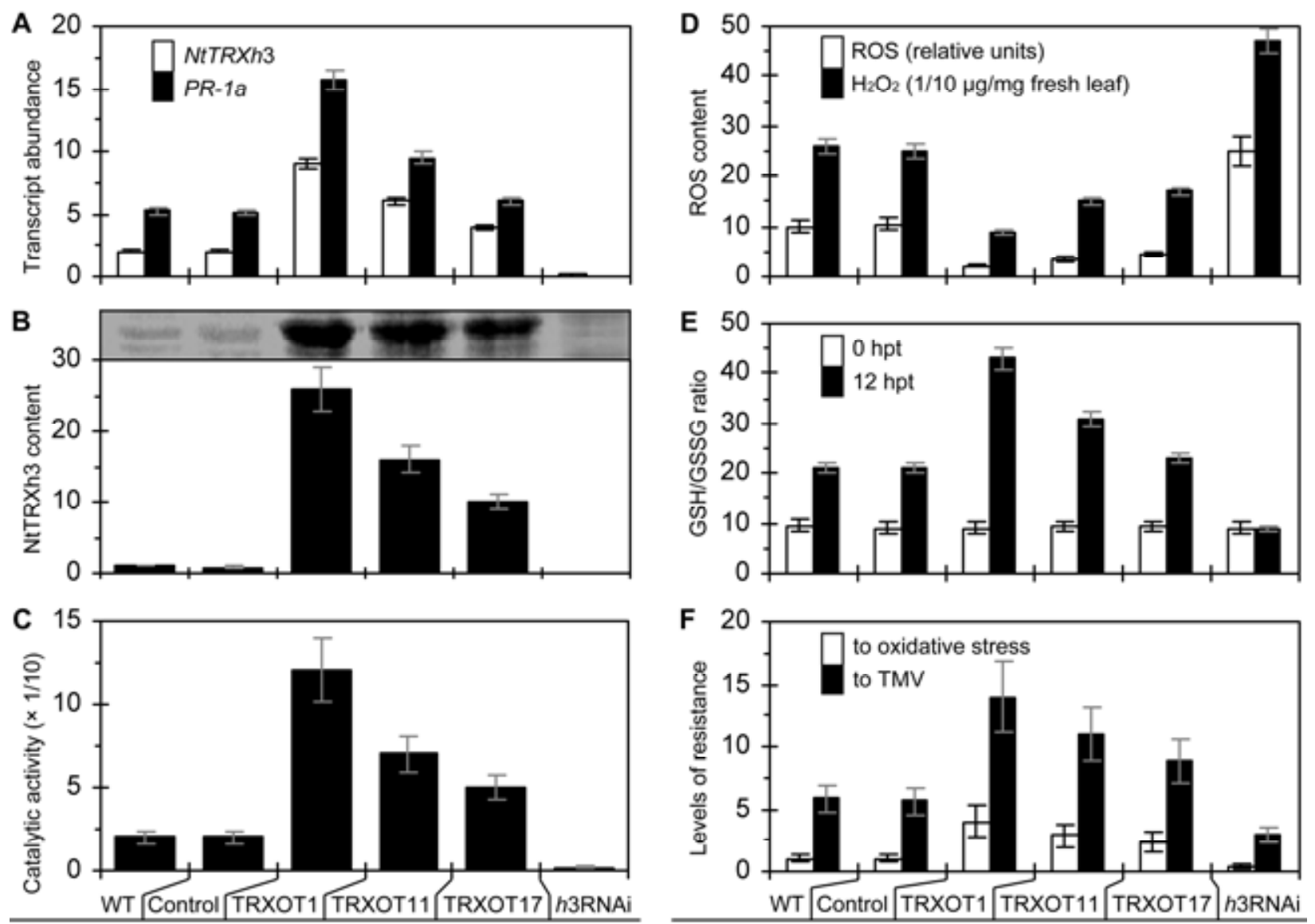

Fig. 10. Integrated tests to correlate NtTRXh3 gene expression and NtTRXh3 protein production with defense responses in the different tobacco genotypes. A through $\mathbf{C}$, Plants were treated with $\mathrm{HrpN}_{\mathrm{Ea}}$ applied to the first and second leaves and investigated $24 \mathrm{~h}$ later. A, Real-time reverse-transcriptase polymerase chain reaction analyses of genes expressed in the untreated fourth and fifth leaves. Transcript abundance at $0 \mathrm{~h}$ posttreatment (hpt) was assigned as 1 . B, Analysis of NtTRXh3 protein. The blot of proteins from $2 \mathrm{~g}$ of leaves of each genotype was probed with the specific anti-NtTRXh3 antibody. Relative content of NtTRXh3 was measured with a gel documentation system. C, Insulin reduction test. Each protein sample was from $2 \mathrm{~g}$ of leaves of each genotype and was subjected to a 45-min reaction with insulin and dithiothreitol. The ability of protein samples to catalyze the reduction of insulin by dithiothreitol was determined with a spectrophotometer. D and E, Twenty-four hours after plants were treated with $\mathrm{HrpN}_{\mathrm{Ea}}$ applied to the first and second leaves, the fourth and fifth leaves were treated with paraquat. D, Reactive oxygen species (ROS) levels quantified at $24 \mathrm{hpt}$ with paraquat. Total ROS levels were quantified as fluorescence intensity of leaves, and $\mathrm{H}_{2} \mathrm{O}_{2}$ content was determined by photospectrometry of leaf extracts. E, Glutathione/glutathione disulfide couple (GSH/GSSG) ratio determined at 0 and 24 hpt with paraquat. F, Relative levels of tobacco resistance to paraquat-induced oxidative stress and to Tobacco mosaic virus (TMV) infection. Twenty-four hours after plants were treated with $\mathrm{HrpN}_{\mathrm{Ea}}$, the fourth and fifth leaves were treated with paraquat or inoculated with TMV. Leaf necrosis caused by paraquat and TMV were observed at $12 \mathrm{~h}$ and 7 days, respectively. Resistance level is given as the 10-fold reciprocal value of the lesion area per leaf size ratio. In A through F, "control" refers to the transgenic control plant; data are mean \pm standard deviation of three experiments. 
fide reduction (Fig. 2), which occurs through thiol-disulfide interchange (Holmgren 1979). Therefore, NtTRXh3 possesses biochemical activity as a redox protein.

Unlike NtTRXh3, NtTRXh1 and NtTRXh2 might not be involved in tobacco responses to viruses and paraquat, because no clear change in the expression of these genes was observed in response to virus inoculation or paraquat treatment (Fig. 1). Like NtTRXh3, however, the predicted NtTRXh2 and NtTRXh3 proteins also contain the conserved WC(G/P)PC motif (Brugidou et al. 1993) (Fig. 2). Whether they have redox protein activities remains unclear. In this study, we did not determine any functions of NtTRXh2 and NtTRXh3 but focused on the role of NtTRXh3 in defensive responses.

To our knowledge, most studies about Trx-h proteins have focused on their functions in the regulation of cellular redox status (Blokhina et al. 2010; Gelhaye et al. 2004a and b; Serrato and Cejudo 2003; Tarrago et al. 2010; Traverso et al. 2007). Only a few Trx-h proteins, such as AtTRX-h3 and AtTRX-h5, have been demonstrated to regulate plant defenses against pathogens (Laloi et al. 2004; Reichheld et al. 2002; Sweat and Wolpert 2007; Tada et al. 2008). Our results support the notion that NtTRXh3 is involved in tobacco resistance, as shown by alleviation of both TMV-induced necrotic symptoms on local (inoculated) leaves and CMV-induced malformation in systemic (noninoculated and upper) leaves. Twenty TRXOT plant lines were generated in an attempt to modulate $N t T R X h 3$ expression. Following $\mathrm{HrpN}_{\mathrm{Ea}}$ treatment, NtTRXh3 expression was significantly higher in 17 TRXOT lines compared with transgenic control plants (ANOVA test, $P<0.01$ ) (Table 1 ). The highest-expressing line, TRXOT1, was also more virus resistant and showed much stronger induction of $P R-1 a$ and GST gene expression than transgenic controls (Fig. 3). Both of these genes are molecular markers of the SAR pathway (Ryals et al. 1996), and their expression indicates the development of SAR (Cutt et al. 1988, 1989; Fodor et al. 1997). In addition, TMV-induced GST expression is an antioxidative response that contributes to the suppression of necrotic symptoms in leaves following SAR (Fodor et al. 1997). Thus, GST is an indicator of both activation of the SAR pathway and plant response to oxidative stress. The contribution of NtTRXh3 to the pathway is clearly indicated by the systemic expression of $P R$ $1 a$ and GST, together with the repression of TMVCP and $C M V C P$ expression (Fig. 3). These events were all impaired when NtTRXh3 was silenced by RNAi (Fig. 5), confirming the importance of NtTRXh3 in plant defense responses. Considering that Arabidopsis Trx-h proteins have been shown to regulate SAR (Tada et al. 2008), our results support the idea that the regulation of SAR is likely to be a common function of Trx-h proteins in different species of plants.

SAR induction, alleviation of oxidative stress, and cellular reducing conditions are stimulated directly or indirectly by the thiol-disulfide interchange activity of Trx (Fobert and Despres 2005; Mou et al. 2003; Tada et al. 2008). This redox regulatory mechanism is also critical to the function of NtTRXh3 as a Trx protein (Fig. 2) in paraquat detoxification and ROS scavenging (Fig. 6). Linkages between these two events and genetic modifications of NtTRXh3 were demonstrated by the higher production of ROS by transgenic control plants compared with TRXOT1 plants, and in the greater production of ROS by h3RNAi plants compared with controls (Figs. 6 and 7). In addition, expression of TPRX, an oxidative stress response gene (Horling et al. 2001; Dietz 2003), was induced in genotypes expressing functional NtTRXh3 but not in $h 3 \mathrm{RNAi}$ plants (Fig. 7). These observations suggest that NtTRXh3 participates in tobacco resistance to abiotic oxidative stress.

Furthermore, our results indicate a linkage between the oxidative stress response and reducing cellular conditions, which both involve NtTRXh3 (Figs. 8 and 9). Paraquat causes oxidative stress during photosynthesis in chloroplasts (Preston et al. 1992; Donahue et al. 1997). The organelle may provide the connection between paraquat toxicity and detoxification by NtTRXh3. It has been suggested that subcellular localization of Trx proteins largely determines their physiological functions (Chibani et al. 2009; Gelhaye et al. 2004a, 2005; Meng et al. 2010). Trx proteins are generally assumed to be cytosolic because they lack any transit signals (Florencio et al. 1988). Other localization sites, such as the membrane (Shi and Bhattacharyya 1996), nuclei (Serrato and Cejudo 2003), and mitochondria (Gelhaye et al. 2004b; Meng et al. 2010), have also been proposed, but NtTRXh3 is annotated as predominantly chloroplast-localized. This prediction was confirmed by immunolocalization and Western blotting analyses, which showed exclusive chloroplast localization of NtTRXh3 (Fig. 8) as well as much greater amounts of the protein in TRXOT1 than in other plants (Fig. 9). These results are consistent with the paraquat detoxification activity, subcellular localization, and content of NtTRXh3 in tobacco plants.

Paraquat toxicity is attributable to its inhibitory effect on the production of reducing equivalents in chloroplasts (Donahue et al. 1997; Kopyra and Gwozdz 2003; Preston et al. 1992). The inhibition of reducing equivalents results in excessive production of cellular ROS (Figs. 6 and 7), whereas the elevation of reducing equivalents is coupled with cellular reducing conditions which are accompanied by increases in the GSH/GSSG ratio (May et al. 1998; Schafer and Buettner 2001). The GSH/GSSG ratio was higher in TRXOT1 plants than in other genotypes (Fig. 9), suggesting a contribution of NtTRXh3 to maintaining cellular reducing conditions (Mou et al. 2003; Tada et al. 2008). These data help to explain the role of NtTRXh3 in tobacco resistance to oxidative stress caused by paraquat toxicity.

Comparison of the specific tobacco genotypes suggests that $N t T R X h 3$ gene expression and the NtTRXh3 protein production scale with tobacco resistance to virus infection and abiotic oxidative stress (Fig. 10). Both defensive responses are consistent with the role of NtTRXh3 as a redox protein that contributes to ROS scavenging and cellular reducing conditions (Figs. 9 and 10). Cellular reducing conditions are indispensable for the function of signaling regulators, such as NPR1, in the SAR pathway (Mou et al. 2003; Spoel et al. 2009; Tada et al. 2008), which is enhanced by NtTRXh3 overexpression based on the concomitant increase in $P R-1 a$ expression (Fig. 10). These results, however, do not indicate any roles of $N P R 1$ and $P R-1$ in responses to viruses or oxidative stresses. Increasing attention has been paid to the role of Trx proteins, beyond their intrinsic antioxidant activity, as signaling intermediates (Bashandy et al. 2010; Dal Piaz et al. 2010; Tada et al. 2008). From this perspective, these results should stimulate further mechanistic studies of how Trx proteins coordinate their functions in cellular redox and defense responses. In particular, like paraquat, $\mathrm{HrpN}_{\mathrm{Ea}}$ induces plant hypersensitive cell death (Peng et al. 2003). Whether NtTRXh3 also functions to attenuate $\mathrm{HrpN}_{\mathrm{Ea}}$-induced cell death and how NtTRXh3 coordinates its roles in cell death and resistance represent interesting avenues for further research.

\section{MATERIALS AND METHODS}

\section{Plant treatment.}

WT and transgenic tobacco plants (Nicotiana tabacum L.) cv. Samsun-NN were grown in the greenhouse at 20 to $25^{\circ} \mathrm{C}$ for 30 days before use, unless specified. Plants were treated by spraying aerial parts with a $2 \mu \mathrm{M}$ aqueous solution of paraquat (Sangon Biotech. Co., Ltd., Shanghai Branch, Shanghai, 
China). $\mathrm{HrpN}_{\mathrm{Ea}}$ was produced by the prokaryotic expression system (Wei et al. 1992; Dong et al. 1999) using the pET30a(+) vector, and purified by chromatography (Chen et al. 2008). $\mathrm{HrpN}_{\mathrm{Ea}}$ was used in a $15 \mu \mathrm{g} / \mathrm{ml}$ aqueous solution applied to plants by spraying the first and second basal leaves. Before application, paraquat and $\mathrm{HrpN}_{\mathrm{Ea}}$ solutions were amended with $0.03 \%$ ( vol/vol) of the surfactant Silwet-77 (Momentive Performance Materials Inc., China Branch, Beijing). In experimental controls, the first and second basal leaves were sprayed with pure water in the presence of $0.03 \%$ Silwet- 77 .

\section{Determination of tobacco gene expression.}

Tobacco gene expression was determined by semiquantitative RT-PCR protocols (Dong et al. 2004; Peng et al. 2003b) and real-time RT-PCR protocols (Wu et al. 2010), as described previously. Both types of RT-PCR analyses were conducted with specific primers (Table 2) from RNA isolated from the fourth and fifth leaves of plants. Semiquantitative RT-PCR was done using RT-PCR beads (Amersham Pharmacia Biotech. Inc., Piscataway, NJ, U.S.A.). EFl $\alpha$ was used as a standard reference (Peng et al. 2003b). An established quantitative method (Livak and Schmittgen 2001) was adopted in real-time RT-PCR using ACTIN2 and EF1 $\alpha$ as reference genes (Barbaric et al. 1995; Volkov et al. 2003; Wu et al. 2010). Genes were amplified $<26$ cycles with a range of template concentration increases by $0.5 \mathrm{ng}$ and from 0 to $3.0 \mathrm{ng}$ in $25-\mu \mathrm{l}$ reaction solutions to select desired doses. Reaction treatments, RT-PCR protocols, product cloning, and sequencing verification were performed as described (Dong et al. 2005; Peng et al. 2003b). Products were resolved by agarose gel electrophoresis and visualized by staining with ethidium bromide (Sambrook and Russell 2001). In real-time PCR analysis, the $25-\mu 1$ reaction

Table 2. Genes tested and primers used in this study

\begin{tabular}{|c|c|c|c|c|}
\hline Gene & GenBank accession no. & Primers & Tests & Product size (bp) \\
\hline \multirow[t]{2}{*}{ NtTRXh1 } & X58527 & $\begin{array}{l}\text { 5'-TGGCTGCTAACGATGCTACTTCATC-3' } \\
\text { 5'-ATGCTTCACTATGGTCTGCTGCAAC-3' }^{\prime}\end{array}$ & RT-PCR ${ }^{\mathrm{a}}$ & 353 \\
\hline & & $\begin{array}{l}\text { 5'-CGAGGAGGGACAAGTGTTCGGCTGC-3' } \\
\text { 5'-GCAGTGACAGTAGCAGGAGCAGCAT-3' }\end{array}$ & Real-time RT-PCR & 351 \\
\hline \multirow[t]{2}{*}{ NtTRXh2 } & Z11803 & $\begin{array}{l}\text { 5'-ATGGCAGAGGAAGGACAAGTCATCG-3' } \\
\text { 5'-TACTGATGTGCTTGGCAATGGTCTG-3' }\end{array}$ & RT-PCR & 340 \\
\hline & & $\begin{array}{l}\text { 5'-CTTGGTGCGGTCCCTGTAAGTTCAT-3' } \\
\text { 5'-CTACTGATGTGCTTGGCAATGGTCT-3' }\end{array}$ & Real-time RT-PCR & 232 \\
\hline \multirow[t]{4}{*}{ NtTRXh3 } & AF435818 & $\begin{array}{l}\text { 5'-ATGGGGATTACTGATATGGT-3' } \\
\text { 5'-TTACTGCGGTTGCGTCTCACAT-3' }\end{array}$ & RT-PCR & 459 \\
\hline & & $\begin{array}{l}\text { 5'-GAGTTTGCTGGTGGAAATGTGTGCC-3' } \\
\text { 5'-TTACTGCGGTTGCGTCTCACATACT-3' }\end{array}$ & Real-time RT-PCR & 372 \\
\hline & & $\begin{array}{l}\text { 5'-GCGGATCCATGGGGATTACTG-3' } \\
\text { 5'-GCGAGCTCTTACTGCGGTTGCGTCT-3' }\end{array}$ & Recombination & $475^{\mathrm{b}}$ \\
\hline & & $\begin{array}{l}\text { 5'-GCGGATCCATGGGGATTACTG-3' } \\
\text { 5'-GCTCTAGATTACTGCGGTTGCGTCT-3' }\end{array}$ & Gene silencing & \\
\hline \multirow[t]{2}{*}{$P R-1 a$} & X12737 & $\begin{array}{l}\text { 5'-GTTCTCTTTTCACAATTGCCTTCAT-3' } \\
\text { 5'-GGACTTTCGCCTCTATAATTACCTG-3' }\end{array}$ & RT-PCR & 491 \\
\hline & & $\begin{array}{l}\text { 5'-TTCTCAACAAGACTATTTGGATGCC-3' } \\
\text { 5'-GAACCGAGTTACGCCAAACCACCTG-3' }\end{array}$ & Real-time RT-PCR & 314 \\
\hline \multirow[t]{2}{*}{$G S T$} & D10524 & $\begin{array}{l}\text { 5'-GCGATCAAAGTCCATGGTAG-3' } \\
\text { 5'-TTATTTTTGCAGCTTCTCCA-3' }\end{array}$ & RT-PCR & 639 \\
\hline & & $\begin{array}{l}\text { 5'-CGAGAAGGAGCTGGATTTTGAGTTT-3' } \\
\text { 5'-CAGTGTAAAAGAGTCTCCACCTAAG-3' }\end{array}$ & Real-time RT-PCR & 427 \\
\hline \multirow[t]{2}{*}{$T P R X$} & AJ309009 & $\begin{array}{l}\text { 5'-CACTTCTTTCTTCCAACCCAAAAGC-3' } \\
\text { 5'-CAAAGTATTCTTTGCTACCCTTGGG-3' }\end{array}$ & RT-PCR & 780 \\
\hline & & $\begin{array}{l}\text { 5'-GCAAGCCTTTTGTTTCTCGTGTAGC-3' } \\
\text { 5'-GACTTTCTATCAGTTTGAACCCAGG-3' }\end{array}$ & Real-time RT-PCR & 361 \\
\hline \multirow[t]{2}{*}{$T M V C P$} & AJ011933 & $\begin{array}{l}\text { 5'-ACTCCATCTCAGTTCGTGTTCTTG-3' } \\
\text { 5'-GAGCTCTCGAAAGAGCTCCGATTA-3' }\end{array}$ & RT-PCR & 425 \\
\hline & & $\begin{array}{l}\text { 5'-GTTGAAAATCAGGCGAACCCCACGA-3' } \\
\text { 5'-GAGGTCCAAACCAAACCAGAAGAGC-3' }\end{array}$ & Real-time RT-PCR & 176 \\
\hline \multirow[t]{2}{*}{$C M V C P$} & AY374328 & $\begin{array}{l}\text { 5'-CGTTCACATCTATCACCCTA-3' } \\
\text { 5'-TACTTTCTCATGTCGCCTAT-3' }\end{array}$ & RT-PCR & 343 \\
\hline & & $\begin{array}{l}\text { 5'-GTGGGTGACAGTCCGTAAAGTTCCT-3' } \\
\text { 5'-GTCTTTTGAATACACGAGGACGGCG-3' }\end{array}$ & Real-time RT-PCR & 211 \\
\hline \multirow[t]{2}{*}{$E F 1 \alpha$} & AF120093 & $\begin{array}{l}\text { 5'-AGACCACCAAGTACTACTGCAC-3' } \\
\text { 5'-CCACCAATCTTGTACACATCC-3' }\end{array}$ & RT-PCR & 495 \\
\hline & & $\begin{array}{l}\text { 5'-TGACAAACTAAAGGCTGAGCGTGAC-3' } \\
\text { 5'-CAAAGCCAGTGGTGGAGGCAACAAT-3' }\end{array}$ & Real-time RT-PCR & 185 \\
\hline \multirow[t]{2}{*}{ Actin2 } & X69885 & $\begin{array}{l}\text { 5'-GCTTGCTTACATTGCTCTCGACTAT-3' } \\
\text { 5'-GACACTGTATTTCCTCTCTGGTGGG-3' }\end{array}$ & RT-PCR & 373 \\
\hline & & $\begin{array}{l}\text { 5'-GCTTGCTTACATTGCTCTCGACTAT-3' } \\
\text { 5'-GATAGAGTTGTATGTAGTCTCGTGG-3' }\end{array}$ & Real-time RT-PCR & 202 \\
\hline
\end{tabular}

${ }^{\mathrm{a}} \mathrm{RT}-\mathrm{PCR}=$ reverse transcription-polymerase chain reaction.

b Includes BamHI (underlined) and SacI (in bold) recognition bases. 
mixture was composed of $1 \mu \mathrm{l}$ of first-strand cDNA diluted 1:10, $2.5 \mu \mathrm{M}$ primer, and $1 \times$ SYBR Premix Ex Taq (TaKaRa Biotech. Co., Ltd., Dalian, China). All reactions were performed in triplicate with null-template controls in which cDNA was absent. PCR cycling was: $95^{\circ} \mathrm{C}$ for $3 \mathrm{~min}$, followed by 40 cycles of $30 \mathrm{~s}$ at $95^{\circ} \mathrm{C}, 30 \mathrm{~s}$ at $60^{\circ} \mathrm{C}$, and $30 \mathrm{~s}$ at $72^{\circ} \mathrm{C}$. Tested gene transcripts were quantified relative to EF1 $\alpha$ and ACTIN2. Average expression levels of the tested genes were normalized to control treatments or control plants.

\section{Manipulation of the NtTRXh3 protein.}

Sequence homology searches were performed with the BLAST program. Amino acid sequences were aligned using the Invitrogen Vector NTI Advance Software. Molecular masses were predicted with DNAStar and verified by tricinesodium dodecyl sulfate polyacrylamide gel electrophoresis of proteins (Chen et al. 2008; Schagger and von Jagow 1987). Protein samples were produced by prokaryotic expression. Full-length cDNA of the NtTRXh3 gene was obtained by RTPCR with specific primers (Table 2) using RNA isolated from leaves of $\mathrm{HrpN}_{\mathrm{Ea}}$-treated plants. For prokaryotic expression, NtTRXh3 was cloned into the pET-30a (+) vector as previously described to include an $\mathrm{His}_{(6)}$ tag (Chen et al. 2008). The recombinant vector was transferred into Escherichia coli strain BL21 (DE3) to produce proteins. Protein preparations were purified by nickel chromatography using the HisTrap HP Kit (Amersham Bioscience Corp.) and analyzed by electrophoresis. Protein concentrations were determined by Bradford assay (Bradford 1976).

Insulin reduction assays were used to determine the ability of NtTRXh3 to catalyze thiol-disulfide interchanges by reduction of insulin by dithiothreitol (Holmgren 1979). Reaction solutions in 2-ml tubes contained 0.1 potassium phosphate $(\mathrm{pH}$ 7.0), $0.13 \mathrm{mM}$ insulin, $20 \mathrm{mM}$ EDTA, $0.33 \mathrm{mM}$ dithiothreitol, and 4 or $8 \mu \mathrm{M}$ purified NtTRXh3 protein (or no protein for controls). The catalytic activity was quantified according to absorbance at $650 \mathrm{~nm}$ determined with a spectrophotometer over $65 \mathrm{~min}$.

\section{Antibody preparation.}

Anti-NtTRXh3 antibody was produced by immunizing New Zealand white rabbits (Oryctolagus cuniculus) with the NtTRXh3 protein, produced in the prokaryotic expression system and purified by nickel chromatography. Purified NtTRXh3 $(1 \mathrm{mg} / \mathrm{ml})$ was emulsified thoroughly in equal volumes of Freund's complete adjuvant and Freund's incomplete adjuvant (Sigma-Aldrich Inc., China Branch, Shanghai). Each rabbit was immunized by nape hypodermic with Freund's complete adjuvant/NtTRXh3 emulsion, followed by consolidated immunization conducted 2 weeks later using Freund's complete adjuvant/NtTRXh3 emulsion. The consolidated immunization was done every 2 weeks, two to three times depending on the antiserum titer determined by enzyme-linked immunosorbent assay, which was performed using goat anti-rabbit immunoglobulin G-HRP and companion reagents according to the manufacturer's instructions (Beyotime Institute of Biotechnology, Haimen, Jiangsu Province, China).

\section{Tobacco plant engineering with $N t T R X h 3$.}

To generate NtTRXh3 overexpression plants, full-length cDNA of the NtTRXh3 gene was fused to PPP1, the fusion was cloned into the pBI121 vector, and the recombinant vector was transferred into cells of Agrobacterium tumefaciens EHA105. A suspension of EHA105 cells containing the empty pBI121 vector or the recombinant vector were used to transform tobacco by the leaf disc method (Horsch et al. 1986). Transgenic plants were generated, screened, multiplied, and characterized as described (Peng et al. 2004). T3 homozygous progenies were used in this study. Southern blots were hybridized with digoxigenin-labeled NtTRXh3-specific probe (Wu et al. 2010). For Western blot analysis, proteins were isolated from leaves (Fan and Dong 2002). Blots were incubated with antiNtTRXh3 antiserum prepared as described, and with horseradish peroxidase-conjugated secondary antibody from the BeyoECL Plus Kit (Beyotime Institute of Biotechnology).

The Y35-mediated PTGS system was used as previously described (Huang et al. 2009; Wang et al. 2009). DNA1 and helper vectors were provided by X. Zhou (College of Agricultural and Life Sciences, Zhejiang University, Hangzhou, China). According to previous studies, DNA1 can replicate autonomously but depends on DNA- $\beta$ for dissemination (Huang et al. 2009) and on the helper Begomovirus sp. for systemic spreading (Wu and Zhou 2005). DNA- $\beta$ is also required for the induction of plant symptoms but needs 1.9A for replication and encapsidation (Cai et al. 2004; Qian and Zhou 2005; Qing and Zhou 2009; Tao and Zhou 2008). When DNA$\beta$ is converted into a gene-silencing vector by replacing its open-reading frame with a multiple cloning site, it is still able to replicate but no longer induces plant symptoms (Tao and Zhou 2004). Therefore, in the PTGS system, DNA1 is used with 1.9A to mediate silencing of a target gene when its partial sequence is inserted into the DNA1 vector (Huang et al. 2009). In this study, full-length NtTRXh3 cDNA was obtained by RTPCR with specific primers (Table 2) and RNA isolated from $\mathrm{HrpN}_{\mathrm{Ea}}$-treated WT plants. After confirmation by sequencing, the RT-PCR product was cloned into the DNA1 vector to create DNA1::NtTRXh3. This unit and the helper vector were cotransferred into A. tumefaciens EHA105 cells. A suspension of DNA1::NtTRXh3-containing EHA105 cells mixed with an equal volume of EHA105 cells already transformed with the helper vector was infiltrated into emerging heart leaves of 30day-old tobacco plants. As a control, the empty DNA1 vector without the NtTRXh3 insert was used to transform plants. Fifteen days later, gene silencing efficiency was evaluated by testing the expression of NtTRXh3 in new leaves. The $h 3 \mathrm{RNAi}$ plant, which showed efficient NtTRXh3 silencing, was compared with empty vector-transformed plants and untransformed plants in further investigations.

\section{Plant infection with viruses.}

TMV stock in an aqueous solution was maintained in our laboratory. CMV stock in an aqueous solution was provided by X. Zhou. The fourth or fifth leaves of plants were inoculated with TMV and CMV by rubbing the leaf lamina with a finger dipped in an aqueous solution containing a virus $(1 \mu \mathrm{g} / \mathrm{ml})$ and diatomaceous earth as an abrasive (Dong and Beer 2000). Viruses were substituted with pure water for mock-inoculation controls. TMV-induced necrotic lesions on inoculated local leaves and CMV-induced malformation symptoms on systemic leaves were investigated 7 and 15 days after inoculation, respectively. The number of TMV-caused necrotic lesions on leaves was counted, and lesion diameters were scored directly by using a ruler. Levels of resistance were compared among treatments or the plant genotypes based on variations in the numbers of necrotic lesions per leaf and in lesion diameters. Alternatively, levels of resistance were given as 10-fold reciprocal value of the lesion area per leaf size ratio. Total size of a leaf and the size of lesions on the leaf were determined with the Magic Wand and Edit Tools of Adobe Photoshop as described (Kwack et al. 2005).

\section{Determination of viral gene transcripts.}

Semiquantitative RT-PCR analyses (Dong et al. 2005; Peng et al. 2003b) were performed using RNA samples from differ- 
ent leaves of tobacco and primers specific to $T M V C P$ and $C M V C P$ (Table 2). Total RNA isolated from the fifth and TMV-inoculated leaves was used to amplify $T M V C P$, and total RNA isolated from systemic leaves above the fifth and CMVinoculated leaves was used to amplify $C M V C P$. Two types of experiment controls were devised. In the first, RT-PCR was performed on RNA samples from equivalent leaves of plants mock inoculated with water. In the second control, the tobacco $E F 1 \alpha$ gene was amplified from RNA samples used in the amplification of $T M V C P$ and $C M V C P$. Real-time RT-PCR analyses of $T M V C P$ and $C M V C P$ were performed as for tobacco genes.

\section{Redox status measurement.}

ROS in leaves was visualized by DCFH-DA fluoluminescence (Torres et al. 2006; Wang et al. 2009). Leaf samples were incubated in an aqueous DCFH-DA solution (100 $\mu \mathrm{M} / \mathrm{ml}$ ) at $37^{\circ} \mathrm{C}$ for $20 \mathrm{~min}$, washed with water, and observed under a fluorescence binocular microscope. Leaf photos from fluorescence microscopy were resolved by Adobe Photoshop to determine relative levels of ROS in leaves. Relative levels of ROS were given as the ROS area per leaf size ratio. The total size of a leaf and the size of ROS areas with green fluorescence were determined by the Magic Wand and Edit Tools of Adobe Photoshop as described (Kwack et al. 2005). The content of $\mathrm{H}_{2} \mathrm{O}_{2}$ in leaves was determined from supernatant obtained by centrifugation of leaf homogenates (Wang et al. 2009). The concentration of $\mathrm{H}_{2} \mathrm{O}_{2}$ was quantified by monitoring the absorbance at $415 \mathrm{~nm}$ of the titanium-peroxide complex present in the supernatant (Jiang and Zhang 2001) and evaluated relative to leaf weight. For GSH measurement, plant leaf tissues were ground in liquid nitrogen. The resulting powder was homogenized in $300 \mu \mathrm{l}$ of protein eliminator $\mathrm{M}$ and incubated for $10 \mathrm{~min}$ at $4^{\circ} \mathrm{C}$, followed by centrifugation at $4^{\circ} \mathrm{C}$ and $10,000 \times$ $g$ for $10 \mathrm{~min}$. The supernatant was used to determine concentrations of GSH and its oxidative form (GSSG) using the GSH and GSSG Assay Kit (Beyotime Institute of Biotechnology).

\section{Immunolocalization assay.}

Previously described methods were used (Frens 1973; Hodges et al. 1984). Sections of $9 \mathrm{~mm}^{2}$ were prepared from the fourth leaves of 30-day-old plants, fixed, and embedded with the Lowicryl $\mathrm{K}_{4} \mathrm{M}$ resin (Sigma-Aldrich Inc.). Ultrathin sections made from embedded samples were floated with the aid of nickel grids in distilled water for $2 \mathrm{~min}$ and in the blocking solution ( $1 \%$ bovine serum albumin; $0.02 \%$ polyethylene glycol 20000; $100 \mathrm{mM} \mathrm{NaCl}$; and $1 \% \mathrm{NaN}_{3}$ in $50 \mathrm{mM}$ phosphate buffer, pH7.0) for $30 \mathrm{~min}$. Then, the grids were treated with a solution of rabbit anti-NtTRXh3 antibody, followed by washing in distilled water and blocking solution. Washed grids were incubated for $45 \mathrm{~min}$ with 10 -nm-diameter gold-labeled goat anti-rabbit immunoglobulin G (Boshide Biotechnol. Co., Ltd., Wuhan, China). Final samples were observed under an electronic microscope (H-7650; Hitachi, Tokyo).

\section{Data analysis.}

All experiments were performed three times on 15 plants each. Quantitative data were analyzed by Student's $t$ test to compare treatments with $\mathrm{HrpN}_{\mathrm{Ea}}$ versus water and paraquat versus water. Data were also analyzed by ANOVA test to compare genotypes of the plant. Both types of comparisons were used to evaluate differences in the effects of treatments or plant genotypes on virus infection and oxidative stress in tobacco.

\section{ACKNOWLEDGMENTS}

We thank X. Zhou for the gift of CMV preparation and PTGS vectors and for scrutinizing the manuscript; and John Carr and the two anonymous reviewers for comments on the experimentation and presentation, and for English editing. This study was supported by grants from the National Science Foundation (30771441 and 30525008), National Development Plan of Key Basic Scientific Studies (973 Plan 2006CB101902), and Novel Transgenic Organisms Breeding Project (2009ZX08002-004B and 2008ZX08002-001) in China.

\section{LITERATURE CITED}

Abel, P. P., Nelson, R. S., De, B., Hoffmann, N., Rogers, S. G., Fraley, R. T., and Beachy, R. N. 1986. Delay of disease development in transgenic plants that express the tobacco mosaic virus coat protein gene. Science 232:738-740.

Albertsson, E., Larsson, D. G., and Förlin, L. 2010. Induction of hepatic carbonyl reductase/20beta-hydroxysteroid dehydrogenase mRNA in rainbow trout downstream from sewage treatment works-possible roles of aryl hydrocarbon receptor agonists and oxidative stress. Aquat. Toxicol. 97:243-249.

Alkhalfioui, F., Renard, M., Vensel, W. H., Wong, J., Tanaka, C. K., Hurkman, W. J., Buchanan, B. B., and Montrichard, F. 2007. Thioredoxin-linked proteins are reduced during germination of Medicago truncatula seeds. Plant Physiol. 144:1559-1579.

Atkinson, H. J., and Babbitt, P. C. 2009. Glutathione transferases are structural and functional outliers in the thioredoxin fold. Biochemistry 48:11108-11116.

Barbaric, T., Sugawara, K., Harada, M., and Kusano, T. 1995. Molecular cloning, characterization and expression of an elongation factor $1 \alpha$ gene in maize. Plant Mol. Biol. 29:611-615.

Bashandy, T., Guilleminot, J., Vernoux, T., Caparros-Ruiz, D., Ljung, K., Meyer, Y., and Reichheld, J. P. 2010. Interplay between the NADPlinked thioredoxin and glutathione systems in Arabidopsis auxin signaling. Plant Cell 22:376-391.

Baumann, U., and Juttner, J. 2002. Plant thioredoxins: The multiplicity conundrum. Cell Mol. Life Sci. 59:1042-1057.

Bevan, M. W., Mason, S. E., and Goelet. P. 1985. Expression of tobacco mosaic virus coat protein by a cauliflower mosaic virus promoter in plants transformed by Agrobacterium. EMBO (Eur. Mol. Biol. Organ.) J. 4:1921-1926.

Blokhina, O., and Fagerstedt, K. V. 2009. Reactive oxygen species and nitric oxide in plant mitochondria: Origin and redundant regulatory systems. Physiol. Plant. 138:447-462.

Blokhina, O., and Fagerstedt, K. V. 2010. Oxidative metabolism, ROS and NO under oxygen deprivation. Plant Physiol. Biochem. 48:359-373.

Bower, M. S., Matias, D. D., Fernandes-Carvalho, E., Mazzurco, M., Gu, T., Rothstein, S. J., and Goring, D. R. 1996. Two members of the thioredoxin-h family interact with the kinase domain of a Brassica $\mathrm{S}$ locus receptor kinase. Plant Cell 8:1641-1650.

Bradford, M. M. 1976. A rapid and sensitive method for the quantitation of microgram quantities of protein utilizing the principle of protein-dye binding. Anal. Biochem. 72:248-254.

Brehelin, C., Laloi, C., Setterdahl, A. T., Knaff, D. B., and Meyer, Y. 2004. Cytosolic, mitochondrial thioredoxins and thioredoxin reductases in Arabidopsis thaliana. Photosynth. Res. 79:295-304.

Brugidou, C., Marty, I., Chartier, Y., and Meyer, Y. 1993. The Nicotiana tabacum genome encodes two cytoplasmic thioredoxin genes which are differently expressed. Mol. Gen. Genet. 238:285-293.

Cai, X., Wang, C., Xu, Y., Xu, Q., Zheng, Z., and Zhou X. 2007. Efficient gene silencing induction in tomato by a viral satellite DNA vector. Virus Res. 125:169-175.

Cao, H., Glazebrook, J., Clarke, J. D., Volko, S., and Dong, X. 1997. The Arabidopsis NPR1 gene that controls systemic acquired resistance encodes a novel protein containing ankyrin repeats. Cell 88:57-63.

Chen, L., Qian, J., Qu, S., Long, J., Yin, Q., Zhang, C., Wu, X., Sun, F., Wu, T., Hayes, M., Beer, S. V., and Dong, H. 2008. Identification of specific fragments of $\mathrm{HpaG}_{\mathrm{Xoo}}$, a harpin from Xanthomonas oryzae pv. oryzicola, that induces disease resistance and enhance growth in plants. Phytopathology 98:781-791.

Chibani, K., Couturier, J., Selles, B., Jacquot, J. P., and Rouhier, N. 2009. The chloroplastic thiol reducing systems: Dual functions in the regulation of carbohydrate metabolism and regeneration of antioxidant enzymes, emphasis on the poplar redoxin equipment. Photosynth. Res. 104:75-99.

Culver, J. N., Lindebeck, A. G. C., and Dawson, W. O. 1991. Virus-host interaction: Induction of chlorotic and necrotic responses in plants by tobacco viruses. Annu. Rev. Phytopathol. 29:193-217.

Cutt, J. R., Dixon, D. C., Carr, J. P., and Klessig, D. F. 1988. Isolation and nucleotide sequence of cDNA clones for the pathogenesis-related proteins PR1a, PR1b and PR1c of Nicotiana tabacum cv. Xanthi nc induced by TMV infection. Nucleic Acids Res. 16:9861. 
Cutt, J. R., Harpster, M. H., Dixon, D. C., Carr, J. P., Dunsmuir, P., and Klessig, D. F. 1989. Disease response to tobacco mosaic virus in transgenic tobacco plants that constitutively express the pathogenesis-related $P R 1 b$ gene. Virology 173:89-97.

Dal Piaz, F., Braca, A., Belisario, M. A., and De Tommasi, N. 2010. Thioredoxin system modulation by plant and fungal secondary metabolites Curr. Med. Chem. 17:479-494.

Dietz, K. J. 2003. Plant peroxiredoxins. Annu. Rev. Plant Biol. 54:93-107.

Donahue, J. L., Okpodu, C. M., Cramer, C. L., Grabau, E. A., and Alscher, R. G. 1997. Responses of antioxidants to paraquat in pea leaves (relationships to resistance). Plant Physiol. 113:249-257.

Dong., H., and Beer, S. V. 2000. Riboflavin induces disease resistance in plants by activating a novel signal transduction pathway. Phytopathology 90:801-811.

Dong, H., Delaney, T. P., Bauer, D. W., and Beer, S. V. 1999. Harpin induces disease resistance in Arabidopsis through the systemic acquired resistance pathway mediated by salicylic acid and the NIM1 gene. Plant J. 20:207-215.

Dong, H., Peng, J., Bao, Z., Meng, X., Bonasera, J. M., Chen, G., Beer, S V., and Dong, H. 2004. Downstream divergence of the ethylene signaling pathway for harpin-stimulated Arabidopsis growth and insect defense. Plant Physiol. 136:3628-3638.

Dong, H., Yu, H., Bao, Z., Guo, X., Peng, J., Yao, Z., Chen, G., Qu, S., and Dong, H. 2005. The ABI2-dependent abscisic acid signalling controls HrpN-induced drought tolerance in Arabidopsis. Planta 221:313-327.

Dong, X. 2001. Genetic dissection of systemic acquired resistance. Curr. Opin. Plant Biol. 4:309-314.

Fan, W., and Dong, X. 2002. In vivo interaction between NPR1 and transcription factor TGA2 leads to salicylic acid-mediated gene activation in Arabidopsis. Plant Cell 14:1377-1389.

Florencio, F. J., Yee, B. C., Johnson, T. C., and Buchanan, B. B. 1988. An NADP/thioredoxin system in leaves: Purification and characterization of NADP-thioredoxin reductase and thioredoxin h from spinach. Arch. Biochem. Biophys. 266:496-507.

Fobert, P. R., and Despres, C. 2005. Redox control of systemic acquired resistance. Curr. Opin. Plant Biol. 8:378-382.

Fodor, J., Gullner, G., Adam, A. L., Barna, B., Komives, T., and Kiraly, Z 1997. Local and systemic responses of antioxidants to tobacco mosaic virus infection and to salicylic acid in tobacco (role in systemic acquired resistance). Plant Physiol. 114:1443-1451.

Frens, G. 1973. Controlled nucleation for the regulation of the particle size in monodisperse gold solution. Nat. Phys. Sci. 241:20-22.

Gallie, D. R., Le, H., Caldwell, C., and Browning, K. S. 1998. Analysis of translation elongation factors from wheat during development and following heat shock. Biochem. Biophys. Res. Commun. 245:295-300.

Gelhaye, E., Rouhier, N., Gerard, J., Jolivet, Y., Gualberto, J., Navrot, N., Ohlsson, P. I., Wingsle, G., Hirasawa, M., Knaff, D. B., Wang, H., Dizengremel, P., Meyer, Y., and Jacquot, J. P. 2004a. A specific form of thioredoxin h occurs in plant mitochondria and regulates the alternative oxidase. Proc. Natl. Acad. Sci. U.S.A. 101:14545-14550.

Gelhaye, E., Rouhier, N., and Jacquot, J. P. 2004b. The thioredoxin h system of higher plants. Plant Physiol. Biochem. 42:265-271.

Gelhaye, E., Rouhier, N., Navrot, N., and Jacquot, J. P. 2005. The plant thioredoxin system. Cell Mol. Life Sci. 62:24-35

Gough, C., Hemon, P., Tronchet, M., Lacomme, C., Marco, Y., and Roby, D. 1995. Developmental and pathogen-induced activation of an $m s r$ gene, str $246 C$, from tobacco involves multiple regulatory elements. Mol. Gen. Genet. 247:323-337.

Govrin, E. M., and Levine, A. 2000. The hypersensitive response facilitates plant infection by the necrotrophic pathogen Botrytis cinerea. Curr. Biol. 10:751-757.

Hall, M., Mata-Cabana, A., Akerlund, H. E., Florencio, F. J., Schröder, W., Lindahl, M., and Kieselbach, T. 2010. Thioredoxin targets of the plant chloroplast lumen and their implications for plastid function. Proteomics 10:987-1001.

Hisabori, T., Motohashi, K., Hosoya-Matsuda, N., Ueoka-Nakanishi, H., and Romano, P. G. 2007. Towards a functional dissection of thioredoxin networks in plant cells. Photochem. Photobiol. 83:145-151.

Hodges, G. M., Smolira, M. A., and Livington, D. C. 1984. Scanning electron microscope immuno-cytochemistry in practice. Page 129-142 in: Immunolabelling for Electron Microscopy J. M. Polak and M. Varndell, eds. Elsevier Science Publisher B. V., Amsterdam.

Holmgren, A. 1979. Thioredoxin catalyzes the reduction of insulin disulfides by dithiothreitol and dihydrolipoamide. J. Biol. Chem. 254:96279632

Horling, F., Baier, M., and Dietz, K. J. 2001. Redox-regulation of the expression of the peroxide-detoxifying chloroplast 2-cys peroxiredoxin in the liverwort Riccia fluitans. Planta 214:304-313.

Horsch, R. B., Klee, H. J., Stachel, S., Winans, S. C., Nester, E. W., Rogers, S. G., and Fraley, R. T. 1986. Analysis of Agrobacterium tumefaciens virulence mutants in leaf discs. Proc. Natl. Acad. Sci. U.S.A. 83:2571-2575.

Huang, C., Xie, Y., and Zhou, X. 2009. Efficient virus-induced gene silencing in plants using a modified geminivirus DNA1 component. Plant Biotechnol. J. 7:254-265.

Iturbe-Ormaetxe, I., Escuredo, P. R., Arrese-Igor, C., and Becana, M. 1998. Oxidative damage in pea plants exposed to water deficit or paraquat. Plant Physiol. 116:173-181.

Jiang. H., Song, W., Li, A., Yang, X., and Sun, D. 2010. Identification of genes differentially expressed in cauliflower associated with resistance to Xanthomonas campestris pv. campestris. Mol. Biol. Rep. doi:10.1007/s11033-010-0148-5

Jiang, M., and Zhang, J. 2001. Effect of abscisic acid on active oxygen species, antioxidative defence system and oxidative damage in leaves of maize seedlings. Plant Cell Physiol. 42:1265-1273.

Kandasamy, S., Loganathan, K., Muthuraj, R., Duraisamy, S., Seetharaman, S., Thiruvengadam, R., Ponnusamy, B., and Ramasamy, S. 2009. Understanding the molecular basis of plant growth promotional effect of Pseudomonas fluorescens on rice through protein profiling. Proteome Sci. 7:47.

Kim, J. F., and Beer, S. V. 2000. hrp genes and harpins of Erwinia amylovora: A decade of discovery. Pages 141-162 in: Fire Blight and Its Causative Agent, Erwinia amylovora. J. L. Vanneste, ed. CAB International, Wallingford, U.K.

Kopyra, M., and Gwozdz, E. A. 2003. Antioxidant enzymes in paraquat and cadmium resistant cell lines of horseradish. Biol. Lett. 40:61-69.

Kwack, M. S., Eui Nam Kim, E. N., Lee, H., Kim, J.-W., Chun, S.-C., and Kim, K. D. 2005. Digital image analysis to measure lesion area of cucumber anthracnose by Colletotrichum orbiculare. J. Gen. Plant Pathol. 71:418-421.

Laloi, C., Mestres-Ortega, D., Marco, Y., Meyer, Y., and Reichheld, J. P. 2004. The Arabidopsis cytosolic thioredoxin h5 gene induction by oxidative stress and its W-box-mediated response to pathogen elicitor. Plant Physiol. 134:1006-1016.

Lemaire, S. D., Michelet, L., Zaffagnini, M., Massot, V., and IssakidisBourguet, E. 2007. Thioredoxins in chloroplasts. Curr. Genet. 51:343365.

Liu, B., Wang, K., Gao, H., Mandavilli, B., Wang, J., and Hong, J. 2001. Molecular consequences of activated microglia in the brain: Overactivation induces apoptosis. J. Neurochem. 77:182-189.

Livak, K. J., and Schmittgen, T. D. 2001. Analysis of relative gene expression data using real-time quantitative PCR and the $2^{-\Delta \Delta C T}$ method. Methods 25:402-408.

Marchand, C., Le Marechal, P., Meyer, Y., Miginiac-Maslow, M., IssakidisBourguet, E., and Decottignies, P. 2004. New targets of Arabidopsis thioredoxins revealed by proteomic analysis. Proteomics 4:2696-2706.

May, M. J., Leaver, C., Montagu, M. V., and Dirk, I. 1998. Glutathione homeostasis in plants: Implications for environmental sensing and plant development. J. Exp. Bot. 49:649-667.

Meng, L., Wong, J. H., Feldman, L. J., Lemaux, P. G., and Buchanan, B. B. 2010. A membrane-associated thioredoxin required for plant growth moves from cell to cell, suggestive of a role in intercellular communication. Proc. Natl. Acad. Sci. U.S.A. 107:3900-3905.

Meyer, Y., Vignols, F., and Reichheld, J. P. 2002. Classification of plant thioredoxins by sequence similarity and intron position. Method Enzymol. 347:394-402.

Meyer, Y., Reichheld, J. P., and Vignols, F. 2005. Thioredoxins in Arabidopsis and other plants. Photosynth. Res. 86:419-433.

Meyer, Y., Buchanan, B. B., Vignols, F., and Reichheld, J. P. 2009. Thioredoxins and glutaredoxins: Unifying elements in redox biology. Annu. Rev. Genet. 43:335-367

Montrichard, F., Alkhalfioui, F., Yano, H., Vensel, W. H., Hurkman, W. J., and Buchanan, B. B. 2008. Thioredoxin targets in plants: The first 30 years. J. Proteomics 72:452-474.

Mou, Z., Fan, W., and Dong, X. 2003. Inducers of plant systemic acquired resistance regulate NPR1 function through redox changes. Cell 113:935-944.

Murgia, I., Tarantino, D., Vannini, C., Bracale, M., Carravieri, S., and Soave, C. 2004. Arabidopsis thaliana plants overexpressing thylakoidal ascorbate peroxidase show increased resistance to Paraquat-induced photooxidative stress and to nitric oxide-induced cell death. Plant J. 38:940-953.

Nuruzzaman, M., Gupta, M., Zhang, C., Wang, L., Xie, W., Xiong, L., Zhang, Q., and Lian, X. 2008. Sequence and expression analysis of the thioredoxin protein gene family in rice. Mol. Genet. Genomics 280:139-151.

Oliveira, M. A., Discola, K. F., Alves, S. V., Medrano, F. J., Guimarães, B. G., and Netto, L. E. 2010. Insights into the specificity of thioredoxin reductase-thioredoxin interactions. A structural and functional investigation of the yeast thioredoxin system. Biochemistry 9:3317-3326.

Park, S. K., Jung, Y. J., Lee, J. R., Lee, Y. M., Jang, H. H., Lee, S. S., 
Park, J. H., Kim, S. Y., Moon, J. C., Lee, S. Y., Chae, H. B., Shin, M. R., Jung, J. H., Kim, M. G., Kim, W. Y., Yun, D. J., Lee, K. O., and Lee, S. Y. 2009. Heat-shock and redox-dependent functional switching of an h-type Arabidopsis thioredoxin from a disulfide reductase to a molecular chaperone. Plant Physiol. 150:552-561.

Peng, J., Dong, H., Bao, Z., Dong, H., and Wan, J. 2003a. Cloning of bacteria inducible plant promoters and their activation in transgenic tobacco. J. Nanjing Agric. Univ. 26:36-40.

Peng, J., Dong, H., Dong, H., Delaney, T. P., Bonasera, J. M., and Beer, S. V. 2003b. Harpin-elicited hypersensitive cell death and pathogen resistance require the NDR1 and EDS1 genes. Physiol. Mol. Plant Pathol. 62:317-326.

Peng, J., Bao, Z., Li, P., Chen, G., Wang, J., and Dong, H. 2004. Harpin $_{\mathrm{Xoo}}$ and its functional domains activate pathogen-inducible plant promoters in Arabidopsis. Acta Bot. Sin. 46:1083-1090.

Potters, G., Horemans, N., and Jansen, M. A. 2010. The cellular redox state in plant stress biology - a charging concept. Plant Physiol. Biochem. 48:492-300.

Preston, C., Holtum, J. A., and Powles, S. B. 1992. On the mechanism of resistance to paraquat in Hordeum glaucum and H. leporinum: Delayed inhibition of photosynthetic $\mathrm{O}_{2}$ evolution after paraquat application. Plant Physiol. 100:630-636.

Pulido, P., Cazalis, R., and Cejudo, F. J. 2009. An antioxidant redox system in the nucleus of wheat seed cells suffering oxidative stress. Plant J.57:132-145.

Qian, Y., and Zhou, X. 2005. Pathogenicity and stability of a truncated DNA $\beta$ associated with Tomato yellow leaf curl China virus. Virus Res. 109:159-163.

Qing, L., and Zhou, X. 2009. Trans-replication of, and competition between, DNA $\beta$ satellites in plants inoculated with Tomato yellow leaf curl China virus and Tobacco curly shoot virus. Phytopathology 99:716720.

Reichheld, J.-P., Mestres-Ortega D., Christophe, L., and Meyer, Y. 2002. The multigenic family of thioredoxin $\mathrm{h}$ in Arabidopsis thaliana: Specific expression and stress response. Plant Physiol. Biochem. 40:685690

Ren, X., Liu, F., Bao, Z., Zhang, C., Wu, X., Chen, L., Liu, R., and Dong, H. 2008. Root growth of Arabidopsis thaliana is regulated by ethylene and abscisic acid signaling interaction in response to $\mathrm{HrpN}_{\mathrm{Ea}}$, a bacterial protein of harpin group. Plant Mol. Biol. Rep. 26:225-240.

Rivas, S., Rougon-Cardoso, A., Smoker, M., Schauser, L., Yoshioka, H., and Jones, J. D. 2004. CITRX thioredoxin interacts with the tomato Cf9 resistance protein and negatively regulates defence. EMBO (Eur. Mol. Biol. Organ.) J. 23:2156-2165.

Ryals, J. A., Neuenschwander, U. H., Willits, M. G., Molina, A., Steiner, H. Y., and Hunt, M. D. 1996. Systemic acquired resistance. Plant Cell 8:1809-1819.

Salánki, K., Gellért, Á., Huppert, E., Náray-Szabó G., and Balázs, E. 2004. Compatibility of the movement protein and the coat protein of cucumoviruses is required for cell-to-cell movement J. Gen. Virol. 85:10391048.

Sambrook, J., and Russell, D. W. 2001. Molecular Cloning: A Laboratory Manual. Cold Spring Harbor Laboratory Press, Cold Spring Harbor, NY, U.S.A.

Schafer, F. Q., and Buettner, G. R. 2001. Redox environment of the cell as viewed through the redox state of the glutathione disulfide/glutathione couple. Free Radic. Biol. Med. 30:1191-1212.

Schagger, H., and von Jagow, G. 1987. Tricine-sodium dodecyl sulphatepolyacrylamid gel electrophoresis for the separation of proteins in the range from 1 to $100 \mathrm{kDa}$. Anal. Biochem. 166:368-379.

Schurmann, P., and Jacquot, J. P. 2000. Plant thioredoxin systems revisited. Annu. Rev. Plant Physiol. Plant Mol. Biol. 51:371-400.

Serrato, A. J., and Cejudo, F. J. 2003. Type-h thioredoxins accumulate in the nucleus of developing wheat seed tissues suffering oxidative stress. Planta 217:392-399.

Shi, J., and Bhattacharyya, M. K. 1996. A novel plasma membrane-bound thioredoxin from soybean. Plant Mol. Biol. 32:653-662.

Spoel, S. H., Mou, Z., Tada, Y., Spivey, N. W., Genschik, P., and Dong,
X. 2009. Proteasome-mediated turnover of the transcription coactivator NPR1 plays dual roles in regulating plant immunity. Cell 137:860-872.

Sweat, T. A., and Wolpert, T. J. 2007. Thioredoxin h5 is required for victorin sensitivity mediated by a CC-NBS-LRR gene in Arabidopsis. Plant Cell 19:673-687.

Tada, Y., Spoel, S. H., Pajerowska-Mukhtar, K., Mou, Z., Song, J., Wang, C., Zuo, J., and Dong, X. 2008. Plant immunity requires conformational changes of NPR1 via S-nitrosylation and thioredoxins. Science 321:952-956.

Takahashi, Y., and Nagata, T. 1992. parB: An auxin-regulated gene encoding glutathione S-transferase. Proc. Natl. Acad. Sci. U.S.A. 89:56-59.

Tarrago, L., Laugier, E., Zaffagnini, M., Marchand, C. H., Le Marechal, P., Lemaire, S. D., and Rey, P. 2010. The plant thioredoxin CDSP32 regenerates 1-CYS methionine sulfoxide reductase B activity through the direct reduction of sulfenic acid. J. Biol. Chem. 285:14964-14972.

Tao, X., and Zhou, X. 2004. A modified viral satellite DNA that suppresses gene expression in plants. Plant J. 38:850-860.

Tao, X., and Zhou, X. 2008. Pathogenicity of a naturally occurring recombinant DNA satellite associated with tomato yellow leaf curl China virus. J. Gen. Virol. 89:306-311.

Torres, M. A., Jones, J. D. G., and Dangl, J. L. 2006. Reactive oxygen species signaling in response to pathogens. Plant Physiol. 141:373-378

Traverso, J. A., Vignols, F., Cazalis, R., Pulido, A., Sahrawy, M., Cejudo, F. J., Meyer, Y., and Chueca, A. 2007. PsTRXh1 and PsTRXh2 are both pea h-type thioredoxins with antagonistic behavior in redox imbalances. Plant Physiol. 143:300-311.

Troutman J. L., and Fulton, R. W. 1958. Resistance in tobacco to cucumber mosaic virus. Virology 6:303-316.

Vieira Dos Santos, C., and Rey, P. 2006. Plant thioredoxins are key actors in the oxidative stress response. Trends Plant Sci. 11:329-334.

Volkov, R. A., Panchuk, I. I., and Schöffl, F. 2003. Heat-stress-dependency and developmental modulation of gene expression: The potential of house-keeping genes as internal standards in mRNA expression profiling using real-time RT-PCR. J. Exp. Bot. 54:2343-2349.

Wang, Y., Liu, R., Chen, L., Liang, Y., Wu, X., Li, B., Wu, J., Wang, X., Zhang, C., Wang, Q., Hong, X., and Dong, H. 2009. Nicotiana tabacum TTG1 contributes to ParA1-induced signalling and cell death in leaf trichomes. J. Cell Sci. 122:2673-2685.

Wang, Z., Xiao, Y., Chen, W., Tang, K., and Zhang, L. 2010. Increased vitamin $\mathrm{C}$ content accompanied by an enhanced recycling pathway confers oxidative stress tolerance in Arabidopsis. J. Integr. Plant Biol. 52:400-409.

Wei, Z., Laby, R. J., Zumoff, C. H., Bauer, D. W., He, S., Collmer, A., and Beer, S. V. 1992. Harpin, elicitor of the hypersensitive response produced by the plant pathogen Erwinia amylovora. Science 257:85-88.

Whitham, S., Dinesh-Kumar, S. P., Choi, D., Hehl, R., Corr, C., and Baker, B. 1994. The product of the tobacco mosaic virus resistance gene N: Similarity to toll and the interleukin-1 receptor. Cell 78:11011115.

Wisniewski, L. A., Powell, P. A., Nelson, R. S., and Beachy, R. N. 1990. Local and systemic spread of tobacco mosaic virus in transgenic tobacco. Plant Cell 2:559-567.

Wu, P. J., and Zhou, X. P. 2005 Interaction between a nanovirus-like component and the Tobacco curly shoot virus/satellite complex. Acta Biochim. Biophys. Sin. 37:25-31.

Wu, T., Guo, A., Zhao, Y., Wang, M., Wang, Y., Zhao, D., Li, X., Ren, H., and Dong, H. 2010. Ectopic expression of the rice lumazine synthase gene contributes to defense responses in transgenic tobacco. Phytopathology 100:573-581.

Zhang, C., Bao, Z., Liang, Y., Yang, X., Wu, X., Hong, X., and Dong, H. 2007. Abscisic acid mediates Arabidopsis drought tolerance induced by $\mathrm{HrpN}_{\mathrm{Ea}}$ in the absence of ethylene signaling. Plant Mol. Biol. Rep. 25:98-114.

\section{AUTHOR-RECOMMENDED INTERNET RESOURCE}

Wolf Psort database: wolfpsort.org 